\title{
Consumo de drogas, alcohol y conductas sexuales en los ambientes recreativos nocturnos de Portugal
}

\section{Drugs and alcohol consumption and sexual behaviours in night recreational settings in Portugal}

\author{
| LURDES LOMBA*; JoÃO APÓSTOLO*; \\ FERNANDO MENDES ${ }^{\star *}$
}

$\mid \begin{aligned} & \text { *Profesores adjuntos. Escuela de Enfermería de Coimba - Portugal. } \\ & { }^{\star *} \text { Psicólogo clínico. Presidente de IREFREA Portugal }\end{aligned}$

Enviar correspondencia a:

Lurdes Lomba. Escola Superior de Enfermagem de Coimbra. Rua

5 de Outubro. Apartado 55. 3001-901 Coimbra. Portugal.

mlomba@esenfc.pt

\section{RESUMEN}

Antecedentes: Los ambientes recreativos nocturnos son lugares claves de la socialización de los jóvenes. Entre quienes frecuentan estos lugares, el consumo de alcohol y drogas provoca cambios en la toma de decisiones sobre relaciones sexuales y se asocia a una mayor probabilidad de practicar conductas sexuales de riesgo.

Objetivo: Describir a los jóvenes que salen los fines de semana; analizar las relaciones entre el hecho de ir a dichos lugares y el consumo de alcohol y drogas; estudiar asociaciones entre consumo de sustancias y conductas sexuales.

Métodos: Se utilizó la metodología del respondent-driven sampling (o muestreo dirigido por los entrevistados) en nueve ciudades portuguesas para interrogar a 1.142 jóvenes que asistieron a locales de ocio nocturno.

Resultados: Los participantes salen habitualmente de noche, sobre todo los fines de semana. Las sustancias más consumidas fueron alcohol, cannabis, cocaina y éxtasis. Los consumidores de alcohol y drogas presentan hábitos recreativos nocturnos mucho más arraigados que los no consumidores, y el consumo de drogas aumenta en proporción a las actividades recreativas. En los últimos 12 meses el 83,3\% de los entrevistados habian mantenido relaciones sexuales $(\bar{X}=2,0$ parejas; $S D=2,3)$, el $51,0 \%$ habian practicado sexo bajo la influencia del alcohol, el 22,9\% bajo la influencia de las drogas, y el $46,7 \%$ reconocieron que dicha influencia los había llevado a practicar sexo no seguro. El consumo precoz de alcohol y drogas se asoció, proporcionalmente, a experiencias sexuales precoces. Los consumidores de alcohol y drogas fueron mucho más propensos a adoptar conductas sexuales de riesgo que los no consumidores.

Conclusiones: Disfrutar de los ambientes recreativos nocturnos expone a los jóvenes portugueses a factores ambientales, que combinados con el consumo de sustancias, influyen en el tipo de relaciones entre consumo de alcohol y drogas y conducta sexual.

Palabras clave: ambientes recreativos nocturnos, alcohol, consumo de drogas, conducta sexual. recibido: diciembre 2008 aceptado: junio 2009

\section{ABSTRACT}

Background: Night recreational settings have become a key location for the socialisation of young people. For customers attending these places, the consumption of alcohol and drugs is related to changes in sexual decision making and associated with increased likelihood of engagement in more risky sexual behaviours.

Aim: To identify the characteristics of Portuguese young people who attend nightclubs, pubs and bars; to explore relationships between attendance at these settings and the consumption of alcohol and drugs; to study associations between substance use and sexual behaviour.

Methods: Respondent-driven sampling methodology was used in nine Portuguese cities to survey 1142 young people who attend nightlife leisure locations.

Results: Respondents regularly go out at night, especially at weekends. The most used substances are alcohol, cannabis, cocaine and ecstasy. Alcohol and drugs users have more regular and deeply-rooted night recreation habits than nonusers and drugs consumption increases with increased recreational activities. In the last 12 months, 83.3\% of the respondents have already had sexual intercourse $(\bar{X}=2.0$ partner; $S D=2.3), 51.0 \%$ had sex under the influence of alcohol, $22.9 \%$ under the influence of drugs and $46.7 \%$ agreed that this influence made them have unsafe sex. Early alcohol and drug use was proportionately related to an early sexual experience. Alcohol and drugs users were more likely to adopt more sexual risk behaviours than non-users.

Conclusions: The enjoyment of recreational nightlife settings exposes Portuguese clubbers to environmental factors which, in combination with substance use, may influence the nature of relationships between alcohol and drug use and sexual behaviour.

Key words: nightlife recreational settings, alcohol, drug use, sexual behaviour. 


\section{INTRODUCCIÓN}

E n la mayoría de los ambientes recreativos nocturnos el rock and roll ha perdido protagonismo, cediendo el puesto a la música dance electrónica. Sin embargo, la frase 'sex and drugs and rock and roll' sigue vigente y su significado permanece, pues caracteriza las estrechas relaciones entre la música, las drogas y las actividades sexuales.

Los jóvenes han heredado una sociedad definida por el consumo, en la que el ocio y la diversión son cada vez más populares y se aceptan como parte normal de la vida social y elemento esencial de socialización. En este contexto el consumo es un medio de satisfacer necesidades, pues el fin es divertirse por medio de diferentes elementos como el baile, la música, sofisticados locales de ocio y las drogas'. Un estudio sobre una muestra de clientes de discotecas ingleses ${ }^{2}$ demostró que el $44 \%$ de los consumidores habituales de drogas admitian que tomar drogas era parte integral de su vida social. Por otro lado, el afán de disfrutar de la fiesta, la música y el baile de forma más intensa y de ampliar la experiencia en el tiempo resultan decisivos a la hora de incluir las drogas ilegales en la diversión ${ }^{3}$.

En los ambientes recreativos nocturnos se imponen cada vez más diferentes tipos de música dance electrónica ${ }^{4}$. En Portugal los tres tipos más importantes de música dance electrónica son el Trance, el House y el Techno 5 . La música dance y la cultura de los clubs han sido absorbidas por la cultura juvenil dominante ${ }^{6}$, trasladándose desde las fiestas underground y los festivales gratuitos a las principales discotecas, pubs y bares, centros de ocio y fiestas de pago. No obstante, la música dance sigue asociándose al consumo de drogas².

Para muchos jóvenes portugueses divertirse significa salir con los amigos y disfrutar de actividades relacionadas con la música y el baile. En este contexto los locales de ocio del centro de las ciudades -entornos recreativos de pubs, bares y discotecas- son frecuentados por diferentes grupos de jóvenes las noches de los fines de semana ${ }^{3}$.

Los datos del ESPAD (European School Survey Project on Alcohol and Other Drugs) portugués ${ }^{7}$ muestran un aumento de la experimentación y el consumo reciente y habitual de drogas ilegales. Según otros estudios ${ }^{8}$, el grupo de edad entre 15 y 24 años mostró una mayor prevalencia del consumo de drogas, y el subgrupo entre 20 y 24 años alcanzó las cotas más altas. El informe nacional del EMCDDA (European Monitoring Centre for Drugs and Drug Addiction) ${ }^{9}$ considera a los clientes de discotecas y fiestas portugueses un grupo de jóvenes vulnerable al policonsumo de drogas - p.e. el consumo concurrente de alcohol, cannabis, cocaína y drogas sintéticas- y destaca que el consumo de drogas, el tipo de consumo y los objetivos del mismo están muy vinculados a la cultura de los jóvenes en las discotecas. Sin embargo, el mismo informe comenta los resultados de un estudio reciente en ambientes recreativos europeos, según el cual el porcentaje de consumidores de drogas ilegales en Lisboa es inferior a la media de otras ciudades europeas y que el consumo de sustancias tanto legales como ilegales se inicia a edades más elevadas.

\section{INTRODUCTION}

$\mathrm{n}$ the majority of nightlife recreational settings, rock and roll has lost its leading role and surrendered its position

to electronic dance music. However, the phrase 'sex and drugs and rock and roll' is still alive and its meaning is still current since it continues to characterise the strong relationships between music, drugs and sexual activities.

Young people have inherited a society defined in terms of consumption in which leisure and fun have become increasingly popular and widely accepted as a normal part of social life and an essential element in socialising. In this context consumption is a need-satisfaction method, given that the intention is to have fun using different elements such as dancing, music, sophisticated leisure venues and drugs'. A study carried out on a sample of English clubbers ${ }^{2}$ showed that $44 \%$ of current drug users agreed that taking drugs was an integral part of their social life. Moreover, the desire to enjoy partying, music and dancing more intensively and to extend this experience in time is also decisive in the inclusion of illegal drugs as a part of the party ${ }^{3}$.

Nightlife recreational settings are increasingly dominated by different kinds of electronic dance music ${ }^{4}$. In Portugal the three most important types of electronic dance music are Trance, House and Techno ${ }^{5}$. Dance music and club culture have been absorbed by mainstream youth culture ${ }^{6}$ moving from underground dance parties and free festivals in fields into mainstream nightclubs, pubs and bars, leisure centres and pay parties. Yet, dance music is often associated with drug use ${ }^{2}$.

For many young people in Portugal having fun means hanging out with friends and enjoying activities related to music and dancing. It is against this backdrop that citycentre leisure venues - those recreational settings of pubs, bars and nightclubs - are visited by different groups of young people on weekend nights ${ }^{3}$.

Data from the Portuguese ESPAD survey suggest an increase in experimentation as well as in the recent and current use of almost all illicit drugs. According to other Portuguese studies ${ }^{8}$, the 15-24 age group had a higher prevalence of drug use whereas the 20-24 age subgroup scores the highest values. The EMCDDA national report ${ }^{9}$ considers Portuguese clubbers and party-goers a vulnerable group of young people in relation to polydrug use - ie. the concurrent use of alcohol, cannabis, cocaine and synthetic drugs - and underlines that drug use, type of use and objectives of use are related to the dance culture of young people. However, the same report points to the results from a recent survey in European recreational settings indicating that the percentage of users of illicit drugs in Lisbon is lower than the average for other European cities and that use starts at a higher age for all licit and illicit substances. 
Otros estudios indican un alto nivel de consumo de drogas y alcohol entre los jóvenes clientes de discotecas/bares en toda Europa ${ }^{10-12}$, y confirman la creciente tendencia al policonsumo de drogas ${ }^{3,13,14}$ y a la generalización del consumo de drogas estimulantes ${ }^{15}$. Esta relación entre ambientes recreativos y consumo de sustancias psicoactivas se observa en otros estudios, que han revelado que el consumo de drogas es más habitual entre los clientes de las discotecas que entre los jóvenes en general ${ }^{15-17}$. Asimismo, se ha demostrado que permanecer en esos ambientes durante períodos de tiempo prolongados equivale a más posibilidades de consumo, lo cual subraya la relación positiva entre alcohol, consumo de drogas y ambientes recreativos ${ }^{18}$.

Por otro lado, algunas drogas recreativas actúan como estimulantes sexuales, reduciendo las inhibiciones e incrementando el deseo sexual ${ }^{19,20}$. Rhodes ${ }^{21}$, con respecto a las conductas de riesgo sexual, indica que entre las palabras "sexo" y "drogas" siempre ha habido una "y", lo cual significa que para muchos jóvenes el consumo de drogas conduce a las relaciones sexuales, pues parten de la idea de que el placer del acto sexual aumenta con el consumo de sustancias. Los efectos de las diferentes drogas sobre el deseo y el acto sexual se han estudiado a fondo: el cannabis ${ }^{22}$, la cocaína ${ }^{23}$, el éxtasis ${ }^{24,25}$, las anfetaminas ${ }^{26}$, "poppers» (nitrito de isobutilo) ${ }^{27,28}$ y en fechas más recientes $\mathrm{GHB}^{29}$. Muchas de estas drogas se valoran y consumen por sus efectos sobre las prácticas sexuales ${ }^{30}$. Pero su consumo se asocia a menudo con conductas sexuales de riesgo ${ }^{31}$ y experiencias sexuales efimeras como "ligues de una sola noche»".

No obstante, hay bastante incertidumbre empírica sobre la dinámica concreta de esta relación ${ }^{32}$, y los autores consideran que la investigación debería centrarse en la relación entre la interacción farmacológica de las drogas, las conductas de riesgo sexual y factores sociales y culturales más amplios que influyen en la actividad sexual y en el consumo de drogas en diferentes contextos sociales.

Otra droga recreativa que en la actualidad representa un gran problema social es el alcohol. Europa tiene los niveles de consumo de alcohol más altos del mundo, y la bebida está presente de diversas formas en el simbolismo cultural y las costumbres de todos los países europeos ${ }^{33}$. Por ejemplo, el consumo excesivo de alcohol, lo que se denomina consumo concentrado de alcohol (binge drinking), supone un gran problema en muchos paises, sobre todo entre los jóvenes ${ }^{34}$. Portugal no es una excepción. La principal impresión de los resultados del ESPAD portugués ${ }^{7}$ sobre el consumo de alcohol es que las proporciones registradas son en general bajas si se comparan con la media de la mayoría de paises europeos. Sin embargo, el porcentaje de estudiantes que practican el consumo concentrado de alcohol es mucho más alto (56\%) y se aproxima al promedio europeo. Portugal se asemeja a otros paises europeos de tradición vinícola, en los que los hábitos están cambiando a nuevos tipos de bebidas alcohólicas ${ }^{35}$.

El alcohol es la sustancia más consumida y que más influye en la conducta sexual ${ }^{31}$. Se utiliza para reforzar la confianza ${ }^{36}$ y rebajar las inhibiciones ${ }^{37}$. Un trecho muy corto separa el efecto inicial de desinhibición de la incapacidad
There are several other studies which mention a high level of drug use and alcohol consumption among young regular club/bar goers across Europe $\mathrm{1}^{10-12}$ and polydrug use is confirmed as increasingly becoming the dominant pattern ${ }^{3,13,14}$, with high levels of stimulant drugs use becoming common ${ }^{15}$. This relationship between recreational settings and the use of psychoactive substances is found in other studies which have revealed that drug use is far more prevalent among regular club goers than among young people in general ${ }^{15-17}$. It also has been demonstrated that staying in these environments for longer periods of time determines higher possibilities of consumption, which reinforces the positive relationship between alcohol and drug use and recreational settings ${ }^{18}$.

Furthermore, some recreational drugs act as sexual stimulants, lowering inhibition and increasing sexual drive ${ }^{19,20}$. Rhodes ${ }^{21}$, referring to sexual risk behaviours, emphasizes that the words "sex" and "drugs" always seem to have an "and" between them, underlining that for many young people drug use naturally leads to sexual intercourse, with the idea that the pleasure of the sexual act increases with the use of substances. The effects of different drugs on sexual desire and performance are widely described: for cannabis ${ }^{22}$, cocaine ${ }^{23}$, ecstasy ${ }^{24,25}$, amphetamines ${ }^{26}$, 'poppers'27,28 and, more recently, GHB ${ }^{29}$. Many of these drugs are valued and used for their effects on sexual practices ${ }^{30}$. But their use can be associated with risky sexual behaviour ${ }^{31}$ and ephemeral sexual experiences of the "one night stand" type $^{3}$. Nevertheless, there remains a considerable empirical uncertainty about the precise dynamics of this relationship ${ }^{32}$ and the authors feel that research should focus on the relationship between the pharmacological interaction between drugs and sexual risk behaviour and the broader social, contextual and cultural factors which may influence sexual activity and drug-taking in different social contexts.

Another recreational drug that is at present a major problem is alcohol. Europe has the highest levels of alcohol consumption worldwide, and drinking is embedded in different ways in cultural symbolism and practices across all European countries ${ }^{33}$. For instance, excessive alcohol use, known as 'binge' drinking, is a huge problem in many countries, especially among young people ${ }^{34}$. Portugal is no exception. The main impression from the ESPAD Portuguese ${ }^{7}$ results on alcohol consumption is that the reported proportions are generally low in comparison with the average of most European countries. However, the percentage of students who had been "binge drinking" is much higher (56\%) and very close to the European average. Portugal seems to follow other southern European countries with a wine history, in which drinking trends are changing to new types of alcoholic beverages ${ }^{35}$.

Alcohol is the substance most commonly used which influences sexual behaviour ${ }^{31}$. It is used to gain confidence ${ }^{36}$ and to lower inhibition ${ }^{37}$. The path from the initial effect of disinhibition to the inability to think rationally and the loss of control is very short ${ }^{38}$. When young people drink 
para pensar racionalmente y de la pérdida de control ${ }^{38}$. Los jóvenes que beben demasiado alcohol, tienen más probabilidades de incurrir en prácticas sexuales de riesgo, puesto que el alcohol merma las capacidades cognitivas necesarias para hacer una valoración coste-beneficios de las prácticas sexuales seguras e inseguras ${ }^{39} 4041$.

Tras conducir en estado de embriaguez, el segundo aspecto más relevante de desinhibición asociado a la embriaguez entre los jóvenes es la conducta sexual ${ }^{35}$. Varios estudios citados por Room ${ }^{35}$ indican que la embriaguez es un complemento muy común de las relaciones sexuales entre jóvenes, sobre todo en la primera experiencia sexual. Sin embargo, Rhodes y Stimson ${ }^{32}$ afirman que la psicoactividad no condiciona la desinhibición o control de la conducta, sino que tan solo proporciona un recipiente vacío de conciencia alterada sobre la cultura, la circunstancia y la personalidad, que se llena de significados y explicaciones. No obstante, otros estudios internacionales ${ }^{42-44}$ señalan que los consumidores de alcohol y drogas son sexualmente más activos y más propensos a practicar sexo poco seguro porque tienen más parejas, no siempre utilizan condones e inician antes la actividad sexual. Estudios realizados en Europa indican que un tercio de los jóvenes se encuentran bajo la influencia del alcohol o las drogas cuando tienen su primera relación sexual ${ }^{31}$.

En Portugal hay pocas investigaciones en este campo, pero según un estudio ${ }^{45}$, el $35.2 \%$ de los jóvenes que habian iniciado su vida sexual admitieron que lo habian hecho bajo la influencia del alcohol, y el 22,4\% bajo la influencia de las drogas. Se observaron diferencias de género en un estudio sobre una muestra de universitarios ${ }^{46}$, en el que los hombres eran más propensos que las mujeres a practicar sexo bajo la influencia del alcohol o las drogas.

Esta nueva actitud de los jóvenes ante la conducta sexual, considerada una actividad más a la que pueden acceder fácilmente ${ }^{47,48}$, tiene importantes repercusiones en la salud pública debido al riesgo de contraer VIH y otras enfermedades de transmisión sexual y al incremento de los embarazos no deseados ${ }^{49}$.

\section{MATERIAL Y MÉTODO}

\section{Muestra}

La población objeto de este estudio se compone de jóvenes que frecuentan regularmente ambientes recreativos nocturnos en nueve ciudades portuguesas. Entre esa población se escogió una muestra de 1142 adolescentes y adultos jóvenes de las ciudades de Lisboa, Porto, Coimbra, Angra do Heroísmo, Ponta Delgada, Odivelas, Funchal, Viana do Castelo y Viseu. Los jóvenes se seleccionaron a través del RDS - respondent-driven sampling ${ }^{50}$ - desarrollado y contrastado previamente como herramienta para seleccionar consumidores de drogas recreativas ${ }^{51}$. Los participantes iniciales (semillas) se escogieron de la siguiente forma: dos hombres y dos mujeres de menos de 19 años, y dos participantes de ambos sexos de más de 19 años. Debian ser clientes habituales de pubs y/o discotecas, incluyendo a clientes asiduos de las alcohol excessively they increase the likelihood of risky sexual practices, since alcohol impares the cognitive abilities required to make a cost-benefit assessment of safe and unsafe sexual practices ${ }^{39} 4041$.

After drink-driving, the second major field of disinhibition related to intoxication among young people is sexual behaviour ${ }^{35}$. A number of studies mentioned by Room ${ }^{35}$ suggest that intoxication is a very common accompaniment to sexual play and intercourse among young people, and particularly for a pair's first sexual experience. However, Rhodes and Stimson ${ }^{32}$ underline that psychoactivity does not determine whether behaviour is disinhibited or controlled: it simply provides an empty vessel of altered consciousness for culture, circumstance and personality to load with meanings and explanations. Even so, other international studies ${ }^{42-44}$ point out that alcohol and drug users are more sexually active and more likely to practise unsafe sex such as have more sexual partners, use condoms less regularly and begin sexual activity earlier. Studies in Europe suggest that up to a third of young people are under the influence of alcohol or drugs when they first have sex ${ }^{31}$.

In Portugal there are few research studies in this field but according to one study ${ }^{45}, 35.2 \%$ of young people who had already begun their sexual lives mention having done so under the influence of alcohol and $22.4 \%$ under the influence of drugs. Gender differences were found in a study carried out on a university sample ${ }^{46}$, in which men had more sex under the influence of alcohol or drugs than women.

This new attitude of young people towards sexual behaviour, seen as one more activity which they can easily access ${ }^{47,48}$, has important implications for public health since the risk of HIV infection and other sexually transmitted diseases or unwanted pregnancies increases ${ }^{49}$.

\section{MATERIAL AND METHOD}

\section{Sample}

The target population of this study is composed of young people who regularly go out to nightlife recreational settings in nine Portuguese cities. From this population we selected a sample of 1142 teenagers and young adults in the cities of Lisbon, Porto, Coimbra, Angra do Heroísmo, Ponta Delgada, Odivelas, Funchal, Viana do Castelo and Viseu. The young people were selected using RDS - respondentdriven sampling ${ }^{50}$ - previously developed and validated as a tool to recruit recreational drug users ${ }^{51}$. The initial recruits (seeds) were selected as follows: two males and two females aged $<19$, and two participants from both sexes aged $19+$. Individuals had to be regular users of pubs and/ or clubs including regular customers of mainstream premises (i.e. generic town and city centre venues) and customers of specialist premises (i.e. venues specialising in music 
zonas principales (locales céntricos y genéricos de pueblos y ciudades) y clientes de lugares especiales (locales especializados en música asociada al consumo de drogas, como la música dance electrónica) ${ }^{2}$. Como parte del cuestionario, se pidió a los participantes que reclutasen a tres personas (un amigo íntimo, un conocido y alguien de su entorno) y les pidiesen que participasen en el estudio. Los participantes del segundo grupo repitieron el proceso, que continuó con el objetivo de conseguir una muestra final de aproximadamente 150 participantes en cada ciudad. En otras publicaciones se describen en detalle los procedimientos utilizados para escoger lugares y participantes del estudio ${ }^{52}{ }^{53}$.

El muestreo se llevó a cabo entre mayo y diciembre de 2007. Los jóvenes escogidos para participar en este estudio $(n=1142)$ tenian entre 15 y 35 años, con una edad media de 22,3 (S.D. $=4,0)$. La muestra total contiene más mujeres $(52,5 \%)$ que hombres $(47,5 \%)$, casi todos solteros $(91,4 \%)$, estudiantes $(56,9 \%)$ o con un empleo fijo (28\%), y con educación superior $(53,1 \%)$ o secundaria $(33,2 \%)$. La mayoría viven con sus padres $(66,6 \%)$ y consideran que tienen un estatus socioeconómico medio $(63,1 \%)$ o medio/alto $(22,4 \%)$.

\section{Instrumento}

El instrumento utilizado fue la "caracterización del cuestionario de población", parte del proyecto "La cultura recreativa como herramienta para prevenir conductas de riesgo", desarrollado por IREFREA (Instituto Europeo de Estudios sobre Prevención) y adaptado y validado para Portugal por IREFREA Portugal. El presente estudio utilizó las preguntas del antedicho cuestionario más adecuadas para definir las siguientes variables:

> Características sociodemográficas de la muestra: Edad, género, estado civil, educación, ocupación, con quién viven y la propia consideración sobre el estatus socio-económico.

> Caracterización de los hábitos recreativos nocturnos: Preguntas sobre la frecuencia de salidas nocturnas, la duración de cada salida y el número de lugares visitados.

> Sexualidad y conductas sexuales: Preguntas sobre el inicio de la actividad sexual, el número de parejas sexuales, la frecuencia de actividad sexual y las conductas sexuales en los doce meses anteriores, en lo relativo al uso de condones, métodos de control de natalidad y relaciones sexuales bajo la influencia del alcohol o las drogas.

> Consumo de alcohol y drogas: Se estudia el consumo y la edad de inicio en el alcohol y las drogas. Las sustancias más utilizadas se seleccionaron (alcohol, cannabis, cocaína, éxtasis y tranquilizantes/sedantes) para realizar análisis más profundos, porque mostraron los niveles más altos de continuidad en el consumo (véase Tabla 1). associated with drug use; e.g. electronic dance music) ${ }^{2}$. As part of the questionnaire, individuals were asked to recruit three members (a close friend, an acquaintance and one of intermediate association) and ask them to participate in the survey. These second-wave respondents repeated the process and this continued with the aim of recruiting a final sample of approximately 150 respondents in each city. A detailed description of the procedures used for selecting spaces and participants for the study can be found in other publications ${ }^{52} 53$.

The sampling was carried out from May to December 2007. The young people recruited to participate in this study $(n=1142)$ were between $15-35$ years old, with a mean age of 22.3 (S.D. $=4.0$ ). The total sample contains more female $(52.5 \%)$ than male participants $(47.5 \%)$, almost all single (91.4\%), students (56.9\%) or with a fixed employment contract $(28 \%)$, and with higher $(53.1 \%)$ or secondary education (33.2\%). Most of them live with their parents $(66.6 \%)$ and consider themselves to have a medium (63.1\%) or medium/high (22.4\%) socioeconomic status.

\section{Instrument}

The instrument used was the "Characterisation of the Population Questionnaire" part of the project "Recreational culture as a tool to prevent risk behaviours" developed by IREFREA (European Institute of Studies on Prevention) and adapted and validated for Portugal by IREFREA Portugal. The current study used the questions from the above mentioned questionnaire that best helped to define the following variables:

> Sociodemographic characteristics of the sample: Age, gender, civil status, education, occupation, with whom they live and the perceived family socioeconomic status.

$>$ Characterisation of the night recreational habits: Questions such as the frequency of going out at night, how many hours they stay out each night and the number of places visited each night.

$>$ Sexuality and sexual behaviours: Questions related to the beginning of sexual activity, number of sexual partners, frequency of sexual activity and sexual behaviours over the last 12 months, such as the use of condoms, birth control methods and sexual relations under the influence of alcohol or drugs.

$>$ Alcohol and drug use: Consumption and age of first trying alcohol and drugs are studied. The most used substances were therefore selected (alcohol, cannabis, cocaine, ecstasy and tranquilizers/ sedatives) for further analysis, also because they showed the highest levels of continuity of use (see Table 1). 


\section{Procedimientos}

Los datos reunidos se analizaron con el programa SPSS para Windows. Se utilizaron técnicas descriptivas básicas y tests no paramétricos para cotejar las posibles relaciones entre diferentes variables: Kruskal-Wallis, Mann-Whitney y los coeficientes de correlación de rango (Gamma y Rho de Spearman).

\section{RESULTADOS}

\section{Hábitos recreativos nocturnos}

Por término medio los participantes salen seis noches al mes ( $S D=4,9$ noches). La mayoría salen dos de los tres dias del fin de semana (viernes, sábado y domingo). Cada salida nocturna dura una media de seis horas $(\mathrm{SD}=1,9)$. La mayoría de estos jóvenes $(41,5 \%)$ visitan entre dos y cuatro locales cada noche. Las principales razones que determinan la elección de local son que debe ser un lugar donde puedan hacer amigos y bailar y que sea un sitio seguro (no violento), con el tipo de música que les gusta. La mayoría $(58,4 \%)$ considera importante o muy importante que en el local se vendan bebidas alcohólicas baratas, para el 15,3\% es importante o muy importante que no les impidan fumar cannabis, y el $6,0 \%$ cree que es importante o muy importante conseguir drogas con facilidad en el local.

\section{Sexualidad y conductas sexuales}

La mayoría de los participantes $(92,9 \%)$ eran heterosexuales, el 2,9\% homosexuales y el 3,8\% bisexuales. El $83,3 \%$ habian tenido relaciones sexuales y la edad media de inicio de la actividad sexual es 16,9 años ( $S D=2,2$ años). En los doce meses anteriores el 96,3\% de los participantes que habian iniciado su vida sexual se mantuvieron sexualmente activos $y$, por término medio, cada joven practicó sexo tres veces en ese período. El promedio de parejas sexuales fue de $1,9(S D=2,3)$. En este grupo de jóvenes que mantuvieron relaciones sexuales en los 12 meses anteriores, el 51,0\% lo hizo bajo la influencia del alcohol y el 22,9\% bajo la influencia de las drogas.

Se preguntó a los participantes si consideraban las drogas y el alcohol elementos que los llevaban a practicar sexo no seguro. El 46,7\% manifestó que sí, y el $8,2 \%$ confesó haberse arrepentido de practicar sexo bajo el influjo de esas sustancias. El 42,0\% de los participantes practicaban sexo siempre o casi siempre sin condón y el $20,3 \%$ lo hacian a veces. El 8,7\% justificó dicha conducta alegando que estaban demasiado borrachos o "colocados" para usar condón. En los 12 meses anteriores el 24,5\% de los participantes se habian sometido a pruebas para detectar ETS.

\section{Alcohol y consumo de drogas}

La Tabla 1 muestra que el alcohol es la sustancia más consumida, seguido por el cannabis, la sustancia ilegal más

\section{Procedures}

All data gathered were analysed using SPSS for Windows. Basic descriptive techniques and non-parametric tests were used to check for possible relationships between the different variables: Kruskal-Wallis, Mann-Whitney and rank order correlation tests (Gamma and Spearman's rho).

\section{RESULTS}

\section{Nightlife recreational habits}

On average, the respondents go out six nights a month (SD = 4.9 nights). Most of them go out two of the three weekend days (Friday, Saturday and Sunday). Each night out lasts an average of six hours (SD $=1.9)$. The majority of these young people (41.5\%) go to two to four nightlife venues each night. The main reasons guiding the choice of venue are that it should be a place where they can meet friends and dance, and be a safe (ie non-violent) place, with the type of music they prefer. The majority (58.4\%) consider it important or very important that the location sells cheap alcoholic drinks, $15.3 \%$ consider it important or very important that it is not a problem smoking cannabis joints there, and $6.0 \%$ think it is important or very important to get drugs easily in the venue.

\section{Sexuality and sexual behaviours}

Most of the respondents (92.9\%) were heterosexual, $2.9 \%$ were homosexual and $3.8 \%$ were bisexual. $83.3 \%$ have had sexual intercourse and the mean age for beginning sexual activity is 16.9 years ( $S D=2.2$ years). Over the last 12 months $96.3 \%$ of the respondents who had already begun their sexual lives remained sexually active and, on average, each young person had sex three times during that same period. The average number of partners was 1.9 (SD = 2.3). Of this group of young people who had sexual intercourse in the last 12 months, 51.0\% did so under the influence of alcohol and $22.9 \%$ under the influence of drugs.

Participants were asked to give their opinion on drugs and alcohol as elements which influence them possibly having unsafe sex. $46.7 \%$ agreed that this influence exists, and $8.2 \%$ confessed having regretted sex because they were under the influence of these substances. $42.0 \%$ of the respondents had sex always or almost always without a condom and $20.3 \%$ did so sometimes. $8.7 \%$ mentioned as reasons for that behaviour the fact that they were too drunk or too "stoned" to use a condom. Over the last 12 months $24.5 \%$ of the respondents were screened for STDs.

\section{Alcohol and drug use}

Table 1 shows that alcohol is the most used substance followed by cannabis, which is the illicit substance most 
Tabla 1: Consumo de alcohol y drogas

Table 1: Alcohol and drug use

\begin{tabular}{|c|c|c|c|c|c|c|c|}
\hline \multirow[t]{2}{*}{ Sustancia / Substance } & \multicolumn{2}{|c|}{$\begin{array}{c}\text { Consumidores / } \\
\text { Users }\end{array}$} & \multicolumn{2}{|c|}{$\begin{array}{l}\text { Edad del Io consumo (años) / } \\
\text { Age of 1st Consumption (years) }\end{array}$} & \multirow{2}{*}{$\begin{array}{c}\text { Experimentado sólo } 1 \mathrm{vez} / \\
\text { Experimented once only } \\
\mathrm{n}\end{array}$} & \multirow{2}{*}{$\begin{array}{c}\text { Antes si, pero ya no / } \\
\text { Before yes, not anymore } \\
n\end{array}$} & \multirow{2}{*}{$\begin{array}{c}\text { Consumo Activo/Continuo / } \\
\text { Active/Continued Consumption } \\
\%\end{array}$} \\
\hline & $n$ & $\% *$ & $\bar{X}$ & SD & & & \\
\hline Alcohol / Alcohol & 1076 & 94,2 & 15,0 & 2,2 & 30 & 27 & 94,7 \\
\hline Cannabis / Cannabis & 523 & 45,8 & 16,8 & 2,4 & 157 & 95 & 51,8 \\
\hline Cocaina / Cocaine & 118 & 10,3 & 19,5 & 3,2 & 45 & 25 & 40,7 \\
\hline Éxtasis / Ecstasy & 129 & 11,3 & 18,6 & 3,4 & 63 & 41 & 19,4 \\
\hline$L S D / L S D$ & 37 & 3,2 & 18,9 & 2,8 & 22 & 13 & 5,4 \\
\hline Anfetaminas / Amphetamines & 24 & 2,1 & 19,5 & 2,7 & 13 & 5 & 25,0 \\
\hline Heroina / Heroin & 25 & 2,2 & 19,2 & 2,6 & 9 & 12 & 16,0 \\
\hline $\mathrm{GHB} / \mathrm{GHB}$ & 3 & 0,3 & 18,0 & 2,4 & 2 & 0 & 33,3 \\
\hline Ketamina / Ketamine & 9 & 0,8 & 21,8 & 3,2 & 6 & 2 & 11,1 \\
\hline Popper / Popper & 58 & 5,1 & 18,9 & 2,8 & 44 & 10 & 6,9 \\
\hline Psicolicibios / Mushrooms & 76 & 6,7 & 19,2 & 2,7 & 56 & 12 & 10,5 \\
\hline
\end{tabular}

* Los porcentajes se refieren al número total de jóvenes que respondieron las preguntas.

* The percentages relate to the total number of young people who answered the questions.

utilizada por los participantes. La segunda sustancia ilegal más utilizada es el éxtasis, seguido de cerca por la cocaína. Como se ve, la edad de inicio del consumo de alcohol es muy baja ( $\bar{X}=15$ años), igual que la edad de inicio en las drogas ilegales: 16,8 años en el caso del consumo de cannabis. El inicio en las restantes drogas es un poco más tardio (en torno a los 19-20 años). Las sustancias con mayores niveles de continuidad tras el inicio fueron: alcohol $(94,7 \%)$, cannabis $(51,8 \%)$, cocaina $(40,7 \%)$, tranquilizantes $(36,4 \%)$, y éxtasis $(19,4 \%)$.

Se recogió información adicional sobre el consumo de alcohol. De los participantes, el 52,4\% se habian emborrachado en las cuatro semanas anteriores; de ellos, el $34,8 \%$ se habian emborrachado una vez, el 25,6\% dos y el 19,3\% tres o cuatro veces.

\section{Relación entre consumo de alcohol y drogas $y$ variables sociodemográficas (sexo, edad, educación)}

Como se ve en la Tabla 2, entre los consumidores de drogas los hombres consumen alcohol y cannabis más a menudo $(p=0.00)$ que las mujeres. Las diferencias registradas en la frecuencia del consumo por género no son significativas en el caso de los consumidores de "tranquilizantes/sedantes", "cocaína" y "éxtasis".

Se estudiaron también las relaciones entre consumo de alcohol y drogas y edad (correlación de Spearman). Los resultados indican diferencias en la frecuencia de consumo sólo entre los consumidores de cannabis: los participantes más jóvenes consumen cannabis con menos frecuencia que los mayores $\left(r_{s}=-0,16 ; p=0,00\right)$. No se observó correlación significativa en la frecuencia de consumo de otras sustancias según la edad de los consumidores (alcohol: $p=0,30$; tranquilizantes/sedantes: $p=0,91$; cocaína: $p=0,91$ y éxtasis: $p$ $=0,87)$. often tried and used by the respondents. The second most widely used illicit substance is ecstasy, followed closely by cocaine. It can also be seen that the age of first alcohol consumption is very low ( $\bar{X}=15$ years), as is the age of onset of illicit drugs: 16.8 years for cannabis consumption. Initiation to the remaining drugs is slightly later (around 19-20 years). Substances with higher levels of continuity after onset are: alcohol (94.7\%), cannabis (51.8\%), cocaine (40.7\%), tranquilizers (36.4\%), and ecstasy (19.4\%).

Additional information was gathered about alcohol consumption. Of the respondents $52.4 \%$ had been drunk in the last four weeks, of whom $34.8 \%$ were drunk once, $25.6 \%$ twice and $19.3 \%$ three or four times.

\section{Relationship between alcohol \& drug use and sociodemographic variables (sex, age, qualifications)}

As shown in Table 2, amongst drug users, men consume alcohol and cannabis $(p=0.00)$ more often than women. The differences found in the frequency of consumption according to gender are not significant for "tranquilizers/sedatives", "cocaine" and "ecstasy" users.

Relationships between alcohol and drug use and respondent age were also explored (Spearman's correlation test). The results indicate a difference in the frequency of consumption only among the group of cannabis users: younger respondents are less likely than older respondents to be frequent cannabis users $\left(r_{s}=-0.16 ; p=0.00\right)$. No significant correlation was found in the frequency of consumption of other substances according to the age of users (alcohol: $p=$ 0.30 ; tranquilizers/sedatives: $p=0.91$; cocaine: $p=0.91$ and ecstasy: $p=0.87$ ). 
Tabla 2: Diferencias en la frecuencia de consumo de alcohol y drogas por género Table 2: Differences in the frequency of alcohol and drug use according to gender

\begin{tabular}{|c|c|c|c|c|c|}
\hline Frecuencia consumo: / How frequently used: & Género / Gender & $\mathrm{n}$ & Media / Madian & $\bar{X}$ & $\begin{array}{c}\text { Test Mann Whitney Z I } \\
\text { Mann Whitney Test Z }\end{array}$ \\
\hline Alcohol / Alcohol & $\begin{array}{l}\text { hombre / male } \\
\text { mujer / female }\end{array}$ & $\begin{array}{l}520 \\
555\end{array}$ & $\begin{array}{l}6,00 \\
5,00\end{array}$ & $\begin{array}{l}5,85 \\
5,15\end{array}$ & $-9,06 *$ \\
\hline Tranquilizantes/Sedantes / Tranquilizers/Sedatives & $\begin{array}{l}\text { hombre / male } \\
\text { mujer / female }\end{array}$ & $\begin{array}{l}24 \\
64\end{array}$ & $\begin{array}{l}3,00 \\
3,00\end{array}$ & $\begin{array}{l}3,75 \\
3,61\end{array}$ & $-0,03$ \\
\hline Cannabis (porros) / Cannabis (joints) & $\begin{array}{l}\text { hombre / male } \\
\text { mujer / female }\end{array}$ & $\begin{array}{l}309 \\
213\end{array}$ & $\begin{array}{l}4,00 \\
3,00\end{array}$ & $\begin{array}{l}4,35 \\
3,69\end{array}$ & $-3,83^{* *}$ \\
\hline Cocaina / Cocaine & $\begin{array}{l}\text { hombre / male } \\
\text { mujer / female }\end{array}$ & $\begin{array}{l}78 \\
40\end{array}$ & $\begin{array}{l}3,00 \\
3,00\end{array}$ & $\begin{array}{l}3,28 \\
3,38\end{array}$ & $-0,19$ \\
\hline Éxtasis / Ecstasy & $\begin{array}{l}\text { hombre / male } \\
\text { mujer / female }\end{array}$ & $\begin{array}{l}78 \\
50\end{array}$ & $\begin{array}{l}2,00 \\
3,00\end{array}$ & $\begin{array}{l}2,77 \\
2,82\end{array}$ & $-0,53$ \\
\hline
\end{tabular}

Tabla 3: Diferencias en la frecuencia de consumo de alcohol y drogas según la educación. Table 3: Differences in the frequency of alcohol and drug use according to education

\begin{tabular}{|c|c|c|c|c|c|}
\hline Frecuencia consumo: / How frequently used: & $\begin{array}{l}\text { Estudios finalizados /en curso } \\
\text { studies finished/current }\end{array}$ & $n$ & Media / Median & $\bar{X}$ & $\begin{array}{l}\text { Test Kruskal Wallis } \chi 2 \\
\text { Kruskal Wallis Test } \chi 2\end{array}$ \\
\hline Alcohol / Alcohol & $\begin{array}{l}\text { educación obligatoria / compulsory education } \\
\text { educación secundaria / secondary education } \\
\text { educ. sup/universitaria / university/higher educ. }\end{array}$ & $\begin{array}{l}143 \\
348 \\
579\end{array}$ & $\begin{array}{l}6,00 \\
5,00 \\
6,00\end{array}$ & $\begin{array}{l}5,67 \\
5,45 \\
5,46\end{array}$ & $3,67(-)$ \\
\hline Tranquilizantes/Sedantes / Tranquilizers/Sedatives & $\begin{array}{l}\text { educación obligatoria / compulsory education } \\
\text { educación secundaria / secondary education } \\
\text { educ. sup/universitaria / university/higher educ. }\end{array}$ & $\begin{array}{l}14 \\
19 \\
54\end{array}$ & $\begin{array}{l}5,00 \\
3,00 \\
3,00\end{array}$ & $\begin{array}{l}5,14 \\
4,00 \\
3,15\end{array}$ & $10,91\left(^{*}\right)$ \\
\hline Cannabis (porros) / Cannabis (joints) & $\begin{array}{l}\text { educación obligatoria / compulsory education } \\
\text { educación secundaria / secondary education } \\
\text { educ. sup/universitaria / university/higher educ. }\end{array}$ & $\begin{array}{c}78 \\
145 \\
295\end{array}$ & $\begin{array}{l}5,00 \\
3,00 \\
3,00\end{array}$ & $\begin{array}{l}5,21 \\
3,92 \\
3,86\end{array}$ & $30,77(* *)$ \\
\hline Cocaina / Cocaine & $\begin{array}{l}\text { educación obligatoria / compulsory education } \\
\text { educación secundaria / secondary education } \\
\text { educ. sup/universitaria / university/higher educ. }\end{array}$ & $\begin{array}{l}17 \\
36 \\
63\end{array}$ & $\begin{array}{l}4,00 \\
3,00 \\
3,00\end{array}$ & $\begin{array}{l}4,24 \\
3,08 \\
3,19\end{array}$ & $6,98(*)$ \\
\hline Éxtasis / Ecstasy & $\begin{array}{l}\text { educación obligatoria / compulsory education } \\
\text { educación secundaria / secondary education } \\
\text { educ. sup/universitaria / university/higher educ. }\end{array}$ & $\begin{array}{l}21 \\
50 \\
56\end{array}$ & $\begin{array}{l}2,00 \\
3,00 \\
2,00\end{array}$ & $\begin{array}{l}2,62 \\
2,92 \\
2,73\end{array}$ & $1,94(-)$ \\
\hline
\end{tabular}

$\left({ }^{*}\right)$ La diferencia es significativa al nivel 0,05 (2 colas) / $\left({ }^{*}\right)$ Difference is significant at the 0.05 level (2-tailed).

${ }^{(*)}$ La diferencia es significativa al nivel 0.01 (2 colas) / $\left(^{* *}\right)$ Difference is significant at the 0.01 level (2-tailed).

$(-) p=$ irrelevante $/(-) p=$ not significantz

Se hallaron ciertas diferencias en la frecuencia de consumo de tranquilizantes, cannabis o cocaína según el nivel educativo. La Tabla 3 (y también un análisis retrospectivo con el test de Mann Whitney en ambos grupos) indica un consumo más regular de estas tres sustancias por parte de los individuos con educación general básica. En cuanto a los tranquilizantes y al cannabis, los participantes con educación universitaria/superior son quienes los consumen con menor frecuencia. La sustancia menos consumida por los individuos con educación secundaria es la cocaína. No se hallaron diferencias en la frecuencia de consumo de alcohol y éxtasis según el nivel educativo.

\section{Consumo de alcohol y drogas y hábitos recreativos nocturnos}

Como se ve en la Tabla 4, utilizando el test Mann-Whitney y el consiguiente análisis de diferencias entre consumidores y no consumidores de sustancias en cada uno de los indicadores de la variable "hábitos recreativos nocturnos", se deduce que el grupo de jóvenes que consumen alcohol, cannabis, cocaína y éxtasis tienen hábitos recreativos nocturnos más habituales que los no consumidores, sobre todo el grupo
Some differences were found in the frequency of consumption of tranquilizers, cannabis or cocaine according to the qualifications of respondents. Table 3 (and also a post-hoc analysis using the Mann Whitney Test for both groups) points to a more regular consumption of these three substances by individuals with compulsory education. As for the use of tranquilizers and cannabis, respondents with university/ higher education are the ones who use these substances less often. The substance used least often by individuals with secondary education is cocaine. No differences in the frequency of consumption according to the qualifications of the respondents were found for alcohol and ecstasy.

\section{Alcohol \&t drug consumption and night recreational habits}

As shown in Table 4, using the Mann-Whitney test and the subsequent analysis of the differences between substance users and non-users for each of the indicators of the variable "night recreational habits", it can be concluded that the group of young people who use alcohol, cannabis, cocaine and ecstasy has more regular night recreational habits than non-users, especially the group of cannabis 
Tabla 4: Diferencias de hábitos recreativos nocturnos según el consumo de alcohol y drogas

Table 4: Differences in night recreational habits according to alcohol and drug use

\begin{tabular}{|c|c|c|c|c|c|c|c|c|c|c|c|c|c|}
\hline \multirow[t]{2}{*}{ Frecuencia de consumo: } & \multirow[t]{2}{*}{ How frequently used: } & \multicolumn{3}{|c|}{$\begin{array}{l}\text { ¿Cuántas veces (en fin de } \\
\text { semana) has salido } \\
\text { ( } 4 \text { semanas anteriores)? } \\
\text { How many times (at } \\
\text { weekends) have you gone } \\
\text { out (last four weeks) }\end{array}$} & \multicolumn{3}{|c|}{$\begin{array}{l}\text { ¿En fin de semana (vier., sáb. } \\
\text { dom) cuántas veces vas a la } \\
\text { discoteca? } \\
\text { How many nights } \\
\text { over a weekend (Fri,Sat,Sun) } \\
\text { do you go out clubbing }\end{array}$} & \multicolumn{3}{|c|}{$\begin{array}{l}\text { ¿Cuántas horas dura cada } \\
\text { salida nocturna en fin de } \\
\text { semana? } \\
\text { How many hours are you } \\
\text { out at night at the weekend }\end{array}$} & \multicolumn{3}{|c|}{$\begin{array}{l}\text { ¿A cuántos pubs/discotecas } \\
\text { fuiste en tu última salida? } \\
\text { How many pubs/nightclubs } \\
\text { did you visit on your last } \\
\text { night out }\end{array}$} \\
\hline & & $n$ & $\bar{X}$ & z & $n$ & $\bar{X}$ & Z & $n$ & $\bar{X}$ & Z & $n$ & $\bar{X}$ & Z \\
\hline Alcohol / Alcohol & $\begin{array}{l}\text { No consum / Not Users } \\
\text { Consumidor / Users }\end{array}$ & $\begin{array}{c}45 \\
1061\end{array}$ & $\begin{array}{l}5,24 \\
5,85\end{array}$ & $-1,03$ & $\begin{array}{c}47 \\
1070\end{array}$ & $\begin{array}{l}1,53 \\
1,68\end{array}$ & $-1,84$ & $\begin{array}{c}46 \\
1062\end{array}$ & $\begin{array}{l}4,78 \\
5,69\end{array}$ & $\underset{* *}{-3,63}$ & $\begin{array}{c}46 \\
1052\end{array}$ & $\begin{array}{l}2,15 \\
2,55\end{array}$ & $\underset{*}{-2,958}$ \\
\hline $\begin{array}{l}\text { Tranquilizs/Sedantes / } \\
\text { Tranquilizers/Sedatives }\end{array}$ & $\begin{array}{l}\text { No consum / Not Users } \\
\text { Consumidor / Users }\end{array}$ & $\begin{array}{c}1001 \\
88\end{array}$ & $\begin{array}{l}5,84 \\
5,36\end{array}$ & -1.51 & $\begin{array}{c}1011 \\
88\end{array}$ & $\begin{array}{l}1,69 \\
1,50\end{array}$ & $\underset{* *}{-2,59}$ & $\begin{array}{l}1005 \\
87\end{array}$ & $\begin{array}{l}5,62 \\
5,62\end{array}$ & $-0,04$ & $\begin{array}{l}996 \\
87\end{array}$ & $\begin{array}{l}2,52 \\
2,56\end{array}$ & -0.70 \\
\hline $\begin{array}{l}\text { Cannabis (porros) / } \\
\text { Cannabis (joints) }\end{array}$ & $\begin{array}{l}\text { No consum / Not Users } \\
\text { Consumidor / Users }\end{array}$ & $\begin{array}{l}581 \\
516\end{array}$ & $\begin{array}{l}5,25 \\
6,47\end{array}$ & $\begin{array}{l}-4,8 \\
* *\end{array}$ & $\begin{array}{l}585 \\
523\end{array}$ & $\begin{array}{l}1,59 \\
1,76\end{array}$ & $\underset{* *}{-4,56}$ & $\begin{array}{l}585 \\
523\end{array}$ & $\begin{array}{l}5,17 \\
6,21\end{array}$ & $\underset{* *}{-9,32}$ & $\begin{array}{l}582 \\
510\end{array}$ & $\begin{array}{l}2,33 \\
2,78\end{array}$ & $\underset{* *}{-8,22}$ \\
\hline Cocaina / Cocaine & $\begin{array}{l}\text { No consum / Not Users } \\
\text { Consumidor / Users }\end{array}$ & $\begin{array}{l}976 \\
115\end{array}$ & $\begin{array}{l}5,70 \\
6,88\end{array}$ & $-2,44$ & $\begin{array}{l}984 \\
118\end{array}$ & $\begin{array}{l}1,65 \\
1,86\end{array}$ & $\begin{array}{c}-3,10 \\
*\end{array}$ & $\begin{array}{l}978 \\
118\end{array}$ & $\begin{array}{l}5,48 \\
6,95\end{array}$ & $\underset{* *}{-6,88}$ & $\begin{array}{l}971 \\
116\end{array}$ & $\begin{array}{l}2,47 \\
2,98\end{array}$ & $\underset{* *}{-5,66}$ \\
\hline Éxtasis / Ecstasy & $\begin{array}{l}\text { No consum / Not Users } \\
\text { Consumidor / Users }\end{array}$ & $\begin{array}{l}966 \\
127\end{array}$ & $\begin{array}{l}7,17 \\
5,67\end{array}$ & $\underset{* *}{-3,56}$ & $\begin{array}{l}975 \\
128\end{array}$ & $\begin{array}{l}1,65 \\
1,86\end{array}$ & $\underset{* *}{-3,51}$ & $\begin{array}{l}969 \\
127\end{array}$ & $\begin{array}{l}5,46 \\
6,98\end{array}$ & $\underset{* *}{-7,78}$ & $\begin{array}{l}962 \\
125\end{array}$ & $\begin{array}{l}2,46 \\
3,06\end{array}$ & $\underset{* *}{-6,83}$ \\
\hline
\end{tabular}

${ }^{*}$ ) La diferencia es significativa al nivel 0,05 (2 colas) / ( $\left.{ }^{*}\right)$ Difference is significant at the 0.05 level (2-tailed).

$\left({ }^{* *}\right)$ La diferencia es significativa al nivel 0,01 (2 colas / (**) Difference is significant at the 0.01 level (2-tailed).

Tabla 5: Correlación entre consumo de alcohol y drogas y hábitos recreativos nocturnos de los consumidores Table 5: Correlation between alcohol and drug use and night recreational habits of users

\begin{tabular}{|c|c|c|c|c|c|c|c|c|}
\hline \multirow{3}{*}{$\begin{array}{l}\text { Frecuencia de consumo: / } \\
\text { How frequently used: }\end{array}$} & \multirow{2}{*}{\multicolumn{2}{|c|}{$\begin{array}{l}\text { ¿Cuántas veces (en fin de semana) } \\
\text { has salido ( } 4 \text { semanas anteriores)? } \\
\text { How many times (at weekends) } \\
\text { have you gone out (last four } \\
\text { weeks) }\end{array}$}} & \multirow{2}{*}{\multicolumn{2}{|c|}{$\begin{array}{l}\text { ¿En fin de semana (vier., sáb. dom) } \\
\text { cuántas veces vas a la discoteca? } \\
\text { How many nights over a weekend } \\
\text { (Fri,Sat,Sun) do you go out } \\
\text { clubbing }\end{array}$}} & \multirow{2}{*}{\multicolumn{2}{|c|}{$\begin{array}{l}\text { ¿Cuántas horas dura cada salida } \\
\text { nocturna en fin de semana? } \\
\text { How many hours are you out at } \\
\text { night at the weekend }\end{array}$}} & \multirow{2}{*}{\multicolumn{2}{|c|}{$\begin{array}{l}\text { ¿A cuántos pubs/discotecas fuiste } \\
\text { en tu última salida? } \\
\text { How many pubs/nightclubs did } \\
\text { you visit on your last night out }\end{array}$}} \\
\hline & & & & & & & & \\
\hline & $n$ & $r_{s}$ & $n$ & $r_{s}$ & $n$ & $r_{s}$ & $n$ & $r_{5}$ \\
\hline Alcohol / Alcohol & 1061 & $0,32^{* *}$ & 1070 & $0,29^{* *}$ & 1062 & $0,33^{* *}$ & 1052 & $0,30^{* *}$ \\
\hline $\begin{array}{l}\text { Tranquilizs/Sedantes/ } \\
\text { Tranquilizers/Sedatives }\end{array}$ & 88 & $-0,05$ & 88 & $-0,07$ & 87 & $-0,14$ & 87 & 0,00 \\
\hline $\begin{array}{l}\text { Cannabis (porros) / } \\
\text { Cannabis (joints) }\end{array}$ & 516 & $0,15^{* *}$ & 523 & $0,21^{* *}$ & 516 & $0,28^{* *}$ & 510 & $0,22^{* *}$ \\
\hline Éxtasis / Ecstasy & 127 & 0,11 & 128 & 0,12 & 127 & 0,11 & 125 & 0,00 \\
\hline Cocaina / Cocaine & 115 & $0,18^{*}$ & 118 & $0,26^{* *}$ & 118 & 0,09 & 116 & 0,03 \\
\hline
\end{tabular}

${ }^{* *}$ La correlación es significativa al nivel 0,01 (2 colas) / ** Correlation is significant at the 0.01 level (2-tailed).

* La correlación es significativa al nivel 0,05 (2 colas) / * Correlation is significant at the 0.05 level (2-tailed).

de consumidores de cannabis y éxtasis, en el que dicha diferencia se haya presente en todos los indicadores de la variable "hábitos recreativos nocturnos». La tendencia opuesta se observa entre los consumidores de tranquilizantes, cuyos hábitos recreativos nocturnos demuestran que los fines de semana salen menos que los no consumidores.

Para comprobar si los hábitos recreativos nocturnos se diferenciaban en cuanto a frecuencia de consumo en el subgrupo de consumidores de alcohol y drogas, se utilizó un análisis de correlación de ambas variables (véase Tabla 5). Se encontró una correlación positiva, aunque débil, entre el consumo de alcohol y cannabis y los hábitos recreativos nocturnos en todos los indicadores de esta variable, lo cual demuestra que los consumidores más asiduos de estas sustancias tienen hábitos recreativos nocturnos más arraigados. Se observa la misma correlación positiva entre los consumidores de cocaína, aunque sólo en dos de los cuatro indicadores de la variable "hábitos recreativos nocturnos". and ecstasy users, where this difference is present in all indicators of the variable "night recreational habits". The opposite trend is observed in the users of tranquilizers, with differences found in night recreational habits showing that users go out less than non-users on weekends.

In order to check if the nightlife recreational habits differed according to the frequency of consumption in the subgroup of alcohol and drug users, a correlation analysis was used for both variables (see Table 5). A positive but weak correlation was found between alcohol and cannabis consumption and the nightlife recreational habits in all indicators of this variable, showing that the most regular users of these substances have more deep-rooted nightlife recreational habits. The same positive correlation can be observed for cocaine users, although in only two of the four indicators of the variable "night recreational habits". 


\section{Relación entre conducta sexual y consumo de alcohol y drogas}

Se estudiaron las posibles relaciones entre la edad del primer consumo de sustancias y la primera relación sexual (véase Tabla 6). Se observaron correlaciones bajas/moderadas, lo cual indica que los individuos que comenzaron antes a consumir esas sustancias también practicaron sexo antes que los individuos de iniciaron el consumo posteriormente.

El test Mann-Whitney y el consiguiente análisis de las diferencias entre sustancias llevan a la conclusión de que los consumidores de sustancias distintas a los tranquilizantes tuvieron más parejas sexuales y mantuvieron más relaciones bajo la influencia del alcohol que los no consumidores (véase Tabla 7). Los consumidores de cannabis mantuvieron relaciones sexuales sin condón más frecuentemente que los no consumidores. Los consumidores de cannabis, cocaína y éxtasis practicaron sexo sin utilizar ningún medio de control de natalidad y bajo la influencia de las drogas más a menudo que los no consumidores.

Se observaron asociaciones significativas entre conducta sexual y consumo de alcohol y drogas en el grupo de consumidores de alcohol y drogas (véase Tabla 8): el número de parejas sexuales es más elevado entre los jóvenes que consumen alcohol, cannabis y cocaína con mayor frecuencia; los jóvenes que mantuvieron relaciones sexuales sin utilizar ningún medio de control de natalidad consumen alcohol y

\section{Relationship between sexual behaviour and the consumption of alcohol and drugs}

Potential relationships between the age of first substance use and first sexual intercourse were explored (see Table 6). Low/moderate correlations were registered, indicating that individuals who started using these substances earlier also had sex earlier than individuals who used these substances later on in their lives.

Using the Mann-Whitney test and the subsequent analysis of the differences in substances, leads to the conclusion that users of substances other than tranquilizers had more sexual partners and had more sex under the influence of alcohol than non-users (see Table 7). Cannabis users also had sexual intercourse without using condoms more often than non-users. Cannabis, cocaine and ecstasy users had sex without using any form of birth control and under the influence of drugs more often than non-users.

Significant associations between sexual behaviour and consumption of alcohol and drugs were confirmed in the group of alcohol and drugs users (see Table 8): the number of sexual partners is higher amongst young people with the highest frequency of alcohol, cannabis and cocaine consumption; young people who have sex without using any form of birth control use alcohol and cannabis more often; the frequency of sexual intercourse under the influence of

Tabla 6: Correlación entre la edad del primer consumo de alcohol y drogas y la primera experiencia sexual Table 6: Correlation between ages of first alcohol and drug use and first sexual experience

\begin{tabular}{|c|c|c|c|c|c|c|c|c|c|c|}
\hline \multirow{3}{*}{ Sustancia consumo / Substance consume } & \multirow{2}{*}{\multicolumn{2}{|c|}{$\begin{array}{l}\text { Edad ler consumo: } \\
\text { Tranquilizantes } \\
\text { Age of } \text { 1st use: }^{\text {Tranquilizers }}\end{array}$}} & \multirow{2}{*}{\multicolumn{2}{|c|}{$\begin{array}{l}\text { Edad 1 1er consumo: } \\
\text { Alcohol } \\
\text { Age of } 1^{\text {st }} \text { use: } \\
\text { Alcohol }\end{array}$}} & \multirow{2}{*}{\multicolumn{2}{|c|}{$\begin{array}{l}\text { Edad } 1^{\text {er }} \text { consumo: } \\
\text { Cannabis (porros) } \\
\text { Age of } 1^{\text {st }} \text { use: } \\
\text { Cannabis (joints) }\end{array}$}} & \multirow{2}{*}{\multicolumn{2}{|c|}{$\begin{array}{l}\text { Edad 1erconsumo: } \\
\text { Cocaina } \\
\text { Age of 1st use: } \\
\text { Cocaine }\end{array}$}} & \multirow{2}{*}{\multicolumn{2}{|c|}{$\begin{array}{l}\text { Edad 1erConsumo } \\
\text { Éxtasis } \\
\text { Age of 1st use: } \\
\text { Ecstasy }\end{array}$}} \\
\hline & & & & & & & & & & \\
\hline & $n$ & $r_{s}$ & $n$ & $r_{s}$ & $n$ & $r_{s}$ & $n$ & $r_{5}$ & $n$ & $r_{s}$ \\
\hline $\begin{array}{l}\text { Edad } 1^{a} \text { experiencia sexual / } \\
\text { Age of } 1^{\text {st }} \text { sexual experience }\end{array}$ & 78 & $0,23^{*}$ & 866 & $0,36^{* *}$ & 480 & $0,38^{* *}$ & 119 & $0,37^{* *}$ & 123 & $0,39^{* *}$ \\
\hline
\end{tabular}

* La correlación es significativa al nivel 0,05 (2 colas) / * Correlation is significant at the 0.05 level (2-tailed).

** La correlación es significativa al nivel 0,01 ( 2 colas). I ${ }^{* *}$ Correlation is significant at the 0.01 level (2-tailed).

Tabla 7: Diferencias de conducta sexual según el consumo de alcohol y drogas (12 meses anteriores)

Table 7: Differences in sexual behaviours according to alcohol and drugs use (last 12 months)

\begin{tabular}{|c|c|c|c|c|c|c|c|c|c|c|c|c|c|c|c|c|c|c|c|}
\hline \multirow[t]{2}{*}{$\begin{array}{l}\text { Frecuencia de consumo / } \\
\text { How frequently used: }\end{array}$} & & \multicolumn{3}{|c|}{$\begin{array}{l}\text { ¿Con cuántas personas } \\
\text { practicaste sexo? } \\
\text { how many people you had } \\
\text { sex with }\end{array}$} & \multicolumn{3}{|c|}{$\begin{array}{l}\text { ¿Cuántas veces practicaste } \\
\text { sexo? } \\
\text { how many times have you } \\
\text { had sex }\end{array}$} & \multicolumn{3}{|c|}{$\begin{array}{l}\text { ¿Con qué frecuencia } \\
\text { practicas sexo sin condón? } \\
\text { how freg have sex without } \\
\text { using condom }\end{array}$} & \multicolumn{3}{|c|}{$\begin{array}{l}\text { ¿Con qué frecuencia } \\
\text { practicas sexo sin usar } \\
\text { métodos de control de nat? } \\
\text { how freq have sex without } \\
\text { using any form of birth } \\
\text { control }\end{array}$} & \multicolumn{3}{|c|}{$\begin{array}{l}\text { ¿Con qué frecuencia prac- } \\
\text { ticas sexo bajo los efectos } \\
\text { del alcohol? } \\
\text { how freq have sex under } \\
\text { influence of alcohol }\end{array}$} & \multicolumn{3}{|c|}{$\begin{array}{l}\text { ¿Con qué frecuencia prac- } \\
\text { ticas sexo bajo los efectos } \\
\text { de drogas? } \\
\text { how freq have sex under } \\
\text { influence of drugs }\end{array}$} \\
\hline & & $n$ & $\bar{X}$ & Z & $n$ & $\bar{X}$ & Z & $n$ & $\bar{X}$ & Z & $n$ & $\bar{X}$ & Z & $n$ & $\bar{X}$ & z & $n$ & $\bar{X}$ & Z \\
\hline Alcohol / Alcohol & $\begin{array}{l}\text { No-consu / Non-user } \\
\text { consume / User }\end{array}$ & $\begin{array}{l}27 \\
872\end{array}$ & $\begin{array}{l}1,07 \\
1,99\end{array}$ & $\begin{array}{c}-3.03 \\
*\end{array}$ & $\begin{array}{c}29 \\
881\end{array}$ & $\begin{array}{l}2,90 \\
2,94\end{array}$ & $-0,29$ & $\begin{array}{c}30 \\
887\end{array}$ & $\begin{array}{l}2,14 \\
2,20\end{array}$ & $-0,46$ & $\begin{array}{c}30 \\
889\end{array}$ & $\begin{array}{l}2,14 \\
2,20\end{array}$ & $-0,07$ & $\begin{array}{c}30 \\
888\end{array}$ & $\begin{array}{l}1,13 \\
1,67\end{array}$ & $\stackrel{-4,36}{* *}$ & $\begin{array}{c}30 \\
886\end{array}$ & $\begin{array}{l}1,10 \\
1,33\end{array}$ & $-1,833$ \\
\hline $\begin{array}{l}\text { Tranquizs/Sedantes / } \\
\text { Tranquilizers/Sedatives }\end{array}$ & $\begin{array}{l}\text { No-consu / Non-user } \\
\text { consume / User }\end{array}$ & $\begin{array}{c}804 \\
79\end{array}$ & $\begin{array}{l}1,97 \\
1,91\end{array}$ & $-1,07$ & $\begin{array}{l}817 \\
76\end{array}$ & $\begin{array}{l}2,95 \\
2,79\end{array}$ & -1.86 & $\begin{array}{l}822 \\
76\end{array}$ & $\begin{array}{l}2,18 \\
2,32\end{array}$ & $-1,17$ & $\begin{array}{l}825 \\
76\end{array}$ & $\begin{array}{l}1,67 \\
1,89\end{array}$ & $\begin{array}{c}-2,41 \\
(*)\end{array}$ & $\begin{array}{l}824 \\
76\end{array}$ & $\begin{array}{l}1,63 \\
1,78\end{array}$ & $-0,61$ & $\begin{array}{l}822 \\
76\end{array}$ & $\begin{array}{l}1,32 \\
1,37\end{array}$ & $-0,470$ \\
\hline $\begin{array}{l}\text { Cannabis(porros) / } \\
\text { Cannabis(joints) }\end{array}$ & $\begin{array}{l}\text { No-consu / Non-user } \\
\text { consume / User }\end{array}$ & $\begin{array}{l}420 \\
470\end{array}$ & $\begin{array}{l}1,39 \\
2,49\end{array}$ & $\begin{array}{l}-7,78 \\
* *\end{array}$ & $\begin{array}{l}422 \\
477\end{array}$ & $\begin{array}{l}2,89 \\
2,99\end{array}$ & $\stackrel{-2,05}{*}$ & $\begin{array}{l}427 \\
479\end{array}$ & $\begin{array}{l}2,08 \\
2,30\end{array}$ & $\begin{array}{c}-3,21 \\
*\end{array}$ & $\begin{array}{l}429 \\
480\end{array}$ & $\begin{array}{l}1,62 \\
1,79\end{array}$ & $\underset{*}{-3,0}$ & $\begin{array}{l}430 \\
478\end{array}$ & $\begin{array}{l}1,36 \\
1,91\end{array}$ & $\begin{array}{c}-11,53 \\
* *\end{array}$ & $\begin{array}{l}430 \\
476\end{array}$ & $\begin{array}{l}1,04 \\
1,57\end{array}$ & $-13,23$ \\
\hline Cocaina / Cocaine & $\begin{array}{l}\text { No-consu / Non-user } \\
\text { consume / User }\end{array}$ & $\begin{array}{l}776 \\
110\end{array}$ & $\begin{array}{l}1,70 \\
3,80\end{array}$ & $\begin{array}{l}-8,12 \\
* *\end{array}$ & $\begin{array}{l}783 \\
113\end{array}$ & $\begin{array}{l}2,94 \\
2,90\end{array}$ & $-0,71$ & $\begin{array}{l}788 \\
114\end{array}$ & $\begin{array}{l}2,18 \\
2,24\end{array}$ & $-0,61$ & $\begin{array}{l}792 \\
113\end{array}$ & $\begin{array}{l}1,65 \\
1,99\end{array}$ & $\begin{array}{c}-3,45 \\
*\end{array}$ & $\begin{array}{l}792 \\
112\end{array}$ & $\begin{array}{l}1,59 \\
2,06\end{array}$ & $\stackrel{-6,41}{* *}$ & $\begin{array}{l}790 \\
112\end{array}$ & $\begin{array}{l}1,24 \\
1,91\end{array}$ & $\underset{* *}{-11,26}$ \\
\hline Éxtasis / Ecstasy & $\begin{array}{l}\text { No-consu / Non-user } \\
\text { consume / User }\end{array}$ & $\begin{array}{l}767 \\
120\end{array}$ & $\begin{array}{l}1,73 \\
3,48\end{array}$ & $\begin{array}{l}-7,42 \\
* *\end{array}$ & $\begin{array}{l}775 \\
121\end{array}$ & $\begin{array}{l}2,94 \\
2,98\end{array}$ & $-0,27$ & $\begin{array}{l}779 \\
123\end{array}$ & $\begin{array}{l}2,18 \\
2,28\end{array}$ & $-1,11$ & $\begin{array}{l}783 \\
122\end{array}$ & $\begin{array}{l}1,66 \\
1,97\end{array}$ & $\begin{array}{c}-3,61 \\
*\end{array}$ & $\begin{array}{l}784 \\
120\end{array}$ & $\begin{array}{l}1,59 \\
2,08\end{array}$ & $\begin{array}{c}-6,53 \\
*\end{array}$ & $\begin{array}{l}781 \\
121\end{array}$ & $\begin{array}{l}1,24 \\
1,88\end{array}$ & $\underset{* *}{-11,35}$ \\
\hline
\end{tabular}

$\left(^{*}\right)$ La diferencia es significativa al nivel 0,05 (2 colas). / ( $\left.{ }^{*}\right)$ Difference is significant at the 0.05 level (2-tailed).

$\left({ }^{*}\right)$ La diferencia es significativa al nivel 0,01 (2 colas) /. ( $\left.{ }^{* *}\right)$ Difference is significant at the 0.01 level (2-tailed). 
Tabla 8: Correlación entre consumo de alcohol y drogas y conductas sexuales (12 meses anteriores)

Table 8: Correlation between alcohol and drug use and sexual behaviours (last 12 months)

\begin{tabular}{|c|c|c|c|c|c|c|c|c|c|c|}
\hline \multirow{3}{*}{$\begin{array}{l}\text { Actividad sexual } \\
\text { (12 meses anteriores) / } \\
\text { Sexual activity (last } 12 \text { months) }\end{array}$} & \multicolumn{10}{|c|}{ Frecuencia de consumo / How frequently used: } \\
\hline & \multicolumn{2}{|c|}{ Alcohol / Alcohol } & \multicolumn{2}{|c|}{ Cannabis / Cannabis } & \multicolumn{2}{|c|}{ Cocaina / Cocaine } & \multicolumn{2}{|c|}{ Éxtasis / Ecstasy } & \multicolumn{2}{|c|}{ Tranquilzs / Tranquilizers. } \\
\hline & Gamma & n & Gamma & $\mathrm{n}$ & Gamma & $\mathrm{n}$ & Gamma & $n$ & Gamma & $\mathrm{n}$ \\
\hline Personas con las que has practicado sexo / People you had sex with & $0,36^{* *}$ & 872 & $0,32^{* *}$ & 470 & $0,30^{*}$ & 110 & 0,16 & 120 & 0,13 & 79 \\
\hline Veces que has practicado sexo / Times you had sex & 0,01 & 881 & 0,06 & 477 & $-0,02$ & 113 & $-0,09$ & 121 & 0,16 & 76 \\
\hline Sexo sin condón / Sex without condom & $-0,28$ & 887 & $-0,07$ & 479 & 0,15 & 114 & 0,11 & 123 & 0,16 & 76 \\
\hline Sexo sin control de natalidad / Sex without any birth contro & $0,12^{*}$ & 889 & $0,24^{* *}$ & 480 & 0,18 & 113 & 0,16 & 122 & 0,20 & 76 \\
\hline Sexo bajo el efecto del alcohol / Sex under influence of alcohol & $0,51^{* *}$ & 888 & $0,36^{* *}$ & 478 & $0,31^{*}$ & 112 & $0,25^{*}$ & 120 & $-0,10$ & 76 \\
\hline Sexo bajo el efecto de las drogas / Sex under influence of drugs & $0,44^{* *}$ & 886 & $0,77^{* *}$ & 476 & $0,51^{* *}$ & 112 & 0,20 & 121 & 0,21 & 76 \\
\hline
\end{tabular}

** Correlación significativa al nivel 0,01 (2 colas) / **Correlation significant at the 0.01 level (2-tailed)

* Correlación significativa al nivel 0,05 (2 colas). / *Correlation significant at the 0.05 level (2-tailed)

cannabis con mayor frecuencia; la frecuencia de relaciones sexuales bajo el efecto del alcohol y las drogas aumenta a mayor consumo de alcohol, cannabis, cocaína y éxtasis.

\section{DISCUSIÓN}

Este estudio pretende hacer un análisis en profundidad de la situación de Portugal, tratando de descubrir qué tipo de jóvenes acuden a los locales recreativos nocturnos y cómo se divierten, su consumo de alcohol y drogas ilegales, sus conductas sexuales y la interrelación entre esos aspectos. En la muestra se incluyeron jóvenes de ambos sexos, de estatus social medio o medio/alto, y en su mayoría con educación superior.

Los hábitos recreativos nocturnos de los jóvenes portugueses de las nueve ciudades estudiadas siguen un modelo que no se diferencia mucho del típico modelo europeo de diversión y que se puede considerar "normalizado", ya que se adapta al paradigma dominante y en expansión de vida recreativa, consumo y diversión $n^{18,54}$. Los jóvenes de este estudio salen sobre todo los fines de semana (por término medio dos de cada tres noches los fines de semana). Una práctica común y arraigada es la de salir durante largos períodos de tiempo ( $\bar{X}=6$ horas) y cambiar de local de dos a cuatro veces en cada salida. La mayoría de estos portugueses, como otros jóvenes europeos ${ }^{2}$, se divierten relacionándose con los amigos y disfrutando de la música y del baile.

Los estudios sobre el consumo de alcohol de la población en general demuestran que los jóvenes tienden a beber más. Aunque beben menos veces durante la semana, consumen cantidades mucho mayores cuando beben ${ }^{2}$. Un análisis sobre el alcohol consumido por los jóvenes portugueses muestra episodios de consumo de alcohol intensivo, similares a las tasas de prevalencia habitual en la mayoria de los países europeos ${ }^{7}$. En este estudio el alcohol es una sustancia omnipresente desde temprana edad y va desde el consumo ocasional a situaciones de abuso. De hecho, los resultados indican que el consumo excesivo es una de las caracteristicas fundamentales de la diversión, puesto que alcohol or drugs increases with a higher consumption of alcohol, cannabis, cocaine and ecstasy.

\section{DISCUSSION}

This study aimed to provide a more in-depth analysis of the situation in Portugal, trying to understand what type of young people attend to night recreational settings and how they have fun, their use of alcohol and illicit drugs, their sexual behaviours and how these issues are correlated. The sample included young people of both genders, with a medium to medium/high social status, and the majority had higher educational qualifications.

The nightlife recreational habits of Portuguese young people from the nine cities under analysis follow a pattern which is not that different from the typical European pattern of entertainment and can be considered "normalised" since it follows the dominant and expansive paradigm of recreational life, consumption and entertainment ${ }^{18,54}$. The young people in this study go out especially at weekends (on average two out of three weekend nights). A common and well-established practice seems to be staying out at night for long periods of time ( $\bar{X}=6$ hours), as well as changing venues two to four times each evening. For the majority of these Portuguese as for other European clubbers ${ }^{2}$ the enjoyment comes from interacting with friends, enjoying the music and dancing.

Large general population surveys of alcohol consumption show that young people are more likely to drink heavily. Although they drink on fewer occasions during an average week, they consume much larger amounts when they do drink $^{2}$. A focus on the alcohol consumed by Portuguese young people shows heavy episodic drinking, similar to the average prevalence rates of most other European countries ${ }^{7}$. In this study, alcohol is an omnipresent substance from an early age, from occasional consumption to situations of abuse. In fact, the findings point to excessive consumption as one of the key characteristics of entertainment since very frequent consumption ( $26.1 \%$ more than twice a week) and 
se han registrado consumos muy frecuentes (el 26,1\% más de dos veces a la semana) y situaciones muy frecuentes de embriaguez (el 52,4\% se habian emborrachado en las cuatro semanas previas). Estos resultados coinciden con un estudio ${ }^{4}$ que muestra que los clientes de las discotecas beben más a menudo y consumen más alcohol que los adultos jóvenes en general. Se ha observado que el consumo de alcohol es transversal en todos los participantes de la muestra, incluso en los que no salen tan a menudo, lo cual puede ser consecuencia de que en Portugal el alcohol se acepta social y culturalmente como característica integral de los acontecimientos lúdicos, sociales y festivos. Sin embargo, se aprecia un consumo mayor de alcohol entre los participantes que pasan más tiempo fuera de noche y que van a más pubs y discotecas. Consumen más alcohol los hombres, siguiendo la tendencia nacional general ${ }^{7,8}$.

El cannabis, la cocaína y el éxtasis son las sustancias ilegales más consumidas $(45,8 \%, 10,3 \%, 11,3 \%$, respectivamente) en esta muestra, lo cual sigue la tendencia nacional ${ }^{8}$. Sin embargo, la prevalencia de consumo de drogas en esta muestra es mucho más alta que la registrada en la muestra sobre los jóvenes portugueses en general. Estos resultados subrayan los obtenidos por Calvet en un estudio europeo ${ }^{2}$ que vincula estrechamente el consumo de drogas de los jóvenes con «ir" de discotecas ${ }^{4}$.

Según datos de investigaciones recientes ${ }^{7,8}$, la prevalencia del consumo de drogas entre la población portuguesa en general es más baja que la media de la mayoría de los paises europeos. Sin embargo, teniendo en cuenta sólo el consumo de drogas en un ambiente recreativo (clientes de discotecas en la Figura 1), hay un aumento del consumo de cannabis, cocaína y éxtasis, y dicho consumo supera las cifras medias very frequent intoxication (52.4\% had been drunk in the last four weeks) was registered. These results are in line with a study ${ }^{4}$ which suggests that clubbers drink more often and consume more alcohol when they do drink than young adults in general. It was observed that alcohol consumption is transversal to all sample respondents, even those who do not go out so often, which may be a result of the Portuguese social and cultural acceptance of alcohol as an integral feature of social, festive and entertainment events. However, there is higher consumption of alcohol amongst respondents who spend more time out at night and go to a greater number of pubs or nightclubs. Alcohol is consumed mainly by male individuals, following the overall national tendency $y^{7,8}$.

Cannabis, cocaine and ecstasy are the most used illicit substances $(45.8 \%, 10.3 \%, 11.3 \%$, respectively) in this sample, a finding that follows the national trend ${ }^{8}$. Still, the prevalence of drug use in the current sample is much higher than that found in the sample composed of Portuguese young people in general. These results emphasize Calvet's findings in a European study ${ }^{2}$ which firmly links young persons' drug use with 'going out' to clubs ${ }^{4}$.

According to data from recent research ${ }^{7,8}$, the prevalence of drug use among the Portuguese general population is lower than the average of most European countries. However, only taking into account drug use in a recreational setting (Portuguese clubbers in Figure 1), there is an increase in the use of cannabis, cocaine and ecstasy and their use surpasses the average figures for the general population of the selected European countries.

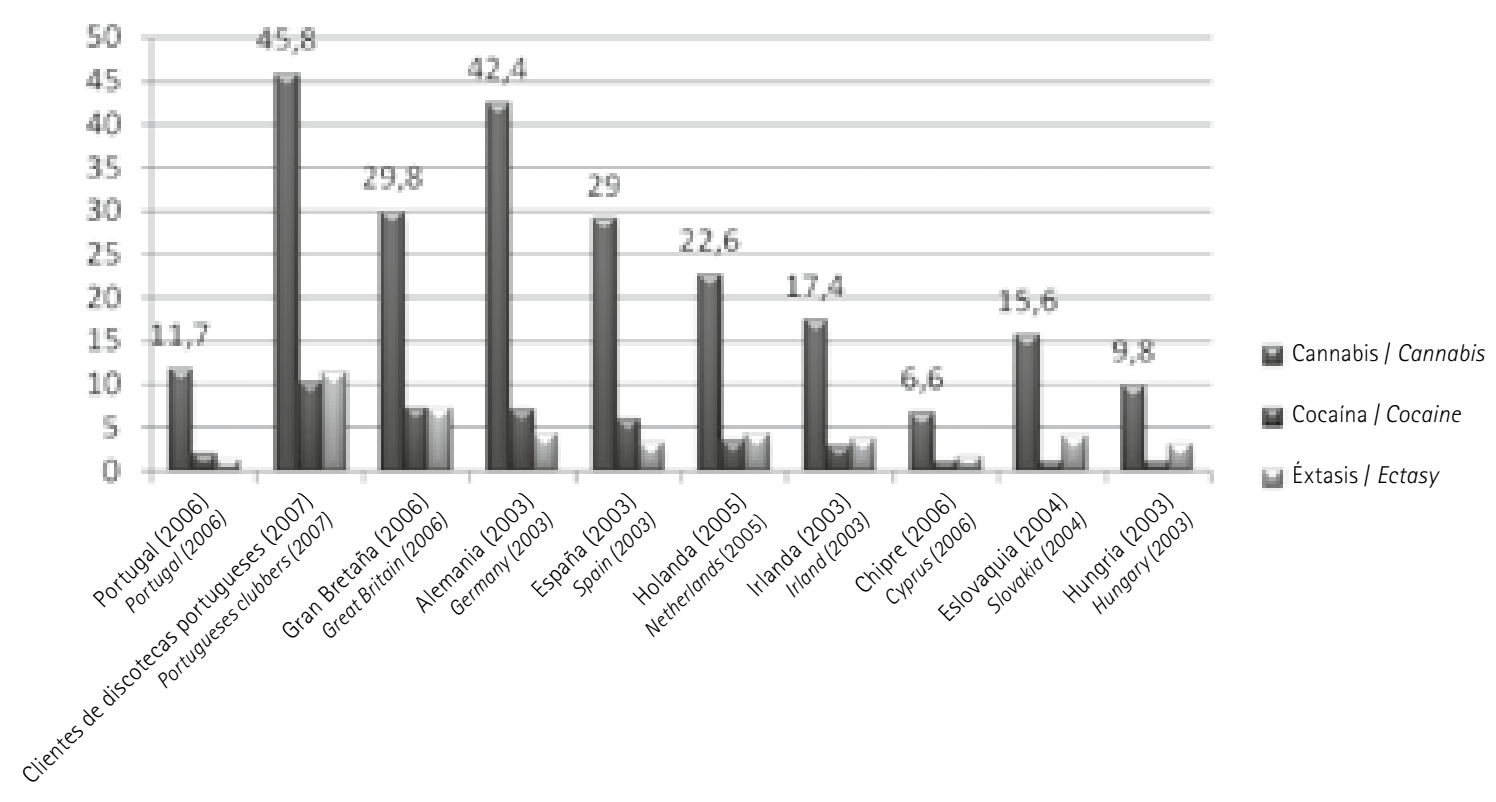

Figura 1: Prevalencia del consumo de drogas entre los clientes de discotecas portuguesas, Portugal y otros países europeos.

Figure 1: Prevalence of drug use in Portuguese clubbers, Portuguese clubbers, Portugal and other European countries 
que registra la población general de los paises europeos seleccionados.

Estos resultados concuerdan con lo que se ha denominado una actitud de "adaptación cultural» ${ }^{54,12}$ al consumo recreativo de drogas ilegales. Como observa Rhodes ${ }^{55(p 193)}$, "los daños de las drogas están condicionados por los entornos de riesgon, y los locales recreativos se pueden considerar entornos de riesgo físico o social, pues se trata de lugares en los que interactúan una serie de factores (individuales, situacionales y culturales) que aumentan los daños provocados por las drogas.

Un estudio nacional ${ }^{15}$ identifica el cannabis como la sustancia ilegal más extentida y consumida por los jóvenes. En dicho estudio el cannabis sigue la tendencia nacional confirmada por otros estudios ${ }^{56}$ : es la primera droga ilegal que se consume, la que con mayor frecuencia consumen los jóvenes y en la que se inician a edad más temprana, siendo el promedio de 16,8 años. El presente estudio confirma que los hombres consumen más cannabis que las mujeres. Esta diferencia de género sigue la tendencia nacional para todas las sustancias mencionadas ${ }^{9}$. Sin embargo, en este estudio no se hallaron diferencias en el consumo de las otras drogas ilegales por género o edad, lo cual puede deberse a la antedicha «normalización» del consumo en los entornos recreativos.

La segunda sustancia ilegal más consumida es el éxtasis $(11,3 \%)$, seguida de cerca por la cocaína $(10,3 \%)$. Estos resultados no siguen la pauta nacional, según la cual la cocaína es la segunda sustancia más consumida por la población general, y su consumo $0^{57,58}$ ha aumentado notablemente. Esta diferencia de resultados obedece seguramente a que el éxtasis (con fama de droga de discoteca) se consume en los ambientes de discotecas ${ }^{59}$, donde se seleccionaron los participantes de esta muestra.

Según este estudio los consumidores de cannabis, éxtasis y cocaína tiene hábitos recreativos más regulares y asentados que los no consumidores en casi todos los indicadores de la variable. Se registró un consumo más habitual de cannabis, éxtasis y cocaína entre el grupo de jóvenes que salen con más frecuencia las noches de los fines de semana, permanecen más tiempo en los locales y visitan más pubs. Estos resultados refuerzan la idea de que los jóvenes consumen drogas, no sólo por divertirse e integrarse en los ambientes recreativos, sino también como apuntan Williams y Parker ${ }^{60}$ "cuando necesitan más energía, capacidad de relación y una excitación más intensa para aguantar durante las largas noches del fin de semana en fiestas o discotecas". La prolongada estancia en pubs y discotecas, el baile como actividad física energética, y el consumo de alcohol (que ocupa un lugar esencial en la diversión, pero tiene efectos depresivos cuando se toma en dosis más altas), redundan en el deseo de consumir sustancias estimulantes como la cocaína o el éxtasis. Esto explica en parte el policonsumo de drogas y el mayor número de horas que los jóvenes pasan en los lugares de diversión. Por otro lado, el elevado consumo de cannabis es normal dentro de esta lógica de la diversión, puesto que se utiliza para "relajarse" de los efectos de las drogas estimulantes consumidas durante la noche.
These findings also agree with what was called of an attitude of "cultural accommodation" 54, 12 to the recreational consumption of illicit drugs. As Rhodes ${ }^{55\left(p^{193)}\right.}$ noted, "drug harms are shaped by risk environments" whereby recreational settings can be considered physical or social risk environments, i.e., places where a variety of factors (individual, situational and cultural) interact and increase the chances of drug-related harm.

A national study ${ }^{15}$ identifies cannabis as the illicit substance most widely experimented and used by young people. In this study cannabis seems to follow the national trend also reported by other studies ${ }^{56}$, ie. it is the first illicit drug tried, it is the most frequently used drug amongst younger respondents and the mean age of onset is the lowest - 16.8 years old. The current study also confirmed that male individuals use cannabis more often than females. This gender difference follows the national trend for all substances mentioned ${ }^{9}$. However, in this study no differences were found in consumption according to gender or user age for the other illicit drugs. This may be due equally to the already mentioned "normalisation" of consumption in recreational settings.

The second most used illicit substance is ecstasy (11.3\%), followed closely by cocaine (10.3\%). These findings do not follow the national trend by which cocaine is the second most used substance by the general population, and whose use $\mathrm{e}^{57,58}$ has been rising sharply. This reversal of results is probably because ecstasy (often known as a club drug) is widely used in the dance scene ${ }^{59}$ where the individuals from this sample were recruited.

This study found that the users of cannabis, ecstasy and cocaine have more regular and well-established recreational habits than non-users in almost all indicators of the variable. More regular use of cannabis, ecstasy and cocaine was observed among the group of young people who: go out more often on weekend nights, stay in these places longer and go to more pubs. These results may reinforce the idea that young people use drugs not only to have fun and get involved in recreational settings but also, as Williams and Parker ${ }^{60}$ point out "when energy, sociability and more intense excitement are required to go out on long weekend nights, party or club". The extended presence in pubs and nightclubs, dancing as an energetic physical activity, together with alcohol consumption (which occupies a central place in entertainment but has a depressive effect when taken in higher doses), results in the desire to use stimulant substances such as cocaine or ecstasy. This may help to explain both polydrug use and the large number of hours spent in entertainment locations. Furthermore, the high consumption of cannabis makes sense in this logic of entertainment, since it is widely used to "chill out" from the effects of taking stimulant drugs during the night.

As for sexual behaviour, most of the respondents had an active sex life (83.3\%) and the mean age for beginning 
En cuanto a conducta sexual, la mayoría de los participantes tenían una vida sexual activa $(83,3 \%)$ y la edad media de inicio de la actividad sexual (16,96 años; SD =2,24 años) es idéntica a los resultados de otro estudio ${ }^{61}$ sobre una muestra de 790 estudiantes universitarios portugueses que iniciaron su actividad sexual a la edad de 16,37 años. El presente estudio descubrió un porcentaje mayor de jóvenes que no usaban condones en comparación con el estudio citado, lo cual se debe a diferencias en las caracteristicas de la muestra. Parece que los jóvenes que van a las discotecas tienen un factor de riesgo contextual mayor a la hora de adoptar conductas de riesgo, como la de no usar condones ${ }^{16}$.

Está clara la relación entre las diferencias en las conductas sexuales de los jóvenes y el consumo de alcohol y drogas. Coincidiendo con estudios previos ${ }^{31,36}$, los consumidores de alcohol y drogas de este estudio manifiestan tendencia a iniciar su vida sexual antes, a tener más parejas sexuales y a adoptar mayor número de conductas sexuales potencialmente peligrosas, si se comparan con los no consumidores. Si restringimos el análisis al grupo de consumidores, hay también diferencias de conductas sexuales entre ellos según los niveles de consumo de diferentes sustancias. Estas diferencias indican un mayor número de parejas sexuales y conductas de riesgo entre el grupo que consume sustancias más a menudo, con mayor prevalencia entre los consumidores de alcohol y cannabis. Pero la evidente correlación entre beber en exceso, consumo de drogas y sexo de riesgo refleja también otros factores ${ }^{62}$, entre los que se incluyen la personalidad y las influencias situacionales y de comportamiento. Aunque esta investigación se ha centrado en la influencia situacional (entornos recreativos nocturnos), no deben olvidarse otros factores. Distintas personas acusan la influencia de factores distintos en las diversas etapas de sus trayectorias como bebedores y consumidores de drogas, y en la conducta sexual influyen también una serie de factores complejos y a veces contradictorios. La existencia de estos factores resulta de gran interés para los programas cuyo objetivo es reducir o prevenir el consumo de drogas potencialmente dañinas o las consecuencias adversas del sexo sin protección. Por ejemplo, convencer a la gente de que no consuma drogas ilegales, de que beba con moderación y se abstenga de practicar sexo de riesgo es loable desde una perspectiva racional y de salud pública. Sin embargo, esta intención choca contra una serie de potentes factores que se deben tener en cuenta si se quiere comprender estas conductas o modificarlas.

El consumo de drogas «relaja inevitablemente las costumbres sexuales y, en consecuencia, lleva a mantener relaciones descuidadas e insegurası ${ }^{31}$. Existe un consenso de sentido común entre los participantes con respecto a esta relación, puesto que el $46,75 \%$ reconocieron que las drogas y el alcohol habian influido en que mantuviesen relaciones sexuales inseguras. Sin embargo, en los 12 meses anteriores, el 8,2\% mantuvieron relaciones de las que se arrepintieron posteriormente debido al consumo de sustancias, y el $24,5 \%$ se sometieron a pruebas de detección de ETS, lo cual demuestra la percepción del riesgo de adoptar estas conductas sexuales. La relajación, la euforia, la desinhibición, la disminución del autocontrol y de la percepción del riesgo provocado sexual activity (16.96 years; SD $=2.24$ years) is identical to the results in another study ${ }^{61}$ with a sample of 790 Portuguese higher education students who began their sexual activity at an average age of 16.37 years. The current study found a higher percentage of young people not using condoms compared with the quoted study which may be related to differences in the sample characteristics. It appears that young people who go clubbing have a higher contextual risk factor for the adoption of risk behaviours, such as not using a condom ${ }^{16}$.

The differences in the sexual behaviours of young people and their association with the use of alcohol and drugs seems clear. In agreement with previous studies ${ }^{31,36}$, alcohol and drug users in this study show a tendency to begin their sex lives earlier, have more sexual partners, and adopt a greater number of potentially risky sexual behaviours compared with non-users. Restricting the analysis to the group of users, there are also intragroup differences in sexual behaviours according to the levels of consumption of the various substances. These differences point to a higher number of sexual partners and risk behaviours among the group who use these substances more often, with a higher prevalence among alcohol and cannabis users. But the evident correlation between heavy drinking, drug use and risky sex could reflect a variety of other factors ${ }^{62}$. These include personality, situational and behavioural influences. Although this research has focused on situational influence (nightlife recreational settings), other factors should not be forgotten. Different people are influenced by different factors at various stages in their drinking and drug-using careers and sexual behaviour is probably also influenced by a variety of complicated and sometimes contradictory factors. The existence of these factors has profound implications for policies aimed at reducing, or preventing, potentially harmful drug use or the adverse consequences of unprotected sex. For instance, persuading people not to use illicit drugs, to drink in moderation and to refrain from risky sex is laudable from a rational and from a public health perspective. However, this intention is actively resisted by many powerful factors which must be taken into account when attempting to understand these behaviours or modify them.

Drug use "must inevitably relax sexual mores and consequently increase carefree and careless sex" 31 . There is a commonsense understanding among the respondents about this relationship since $46.75 \%$ recognised that drugs and alcohol influence them to have unsafe sex. However, in the last 12 months, 8.2\% had sexual intercourse that they regretted afterwards due to the use of these substances, and $24.5 \%$ were screened for STDs, which demonstrates a perception of the risk of adopting these sexual behaviours. Relaxation, euphoria and disinhibition, the decrease in self-control and in the perception of the risk caused by psychoactive substances makes users less cautious and end up forgetting the messages of safe sex which they would take into account if sober ${ }^{3}$. However, Rhodes and Stimson ${ }^{32}$ note that it is not known whether drug use is a marker for 
por las sustancias psicoactivas llevan a los consumidores a ser menos cuidadosos y a que olviden los mensajes de sexo seguro que habrian puesto en práctica si estuviesen sobrios ${ }^{3}$. Sin embargo, Rhodes y Stimson ${ }^{32}$ observan que no se sabe si las drogas son una característica de la conducta sexual de alto riesgo, si el consumo de drogas conduce al sexo de alto riesgo, si el sexo de alto riesgo conduce al consumo de drogas, o si hay existen combinaciones.

Dado que cada vez hay más locales recreativos nocturnos y que gozan de creciente popularidad entre los jóvenes, es esencial para la salud pública centrarse en estos ambientes de riesgo en vez de empeñarse en definir el riesgo epidemiológicamente, como se han limitado a hacer casi en exclusiva los estudios contemporáneos de salud pública sobre adicciones $^{63}$. Rhodes ${ }^{56}$ afirma que es fundamental analizar las situaciones sociales y los lugares en los que se produce o se reduce el daño.

Si las investigaciones futuras pretenden contribuir de forma práctica al diseño y ejecución de intervenciones de reducción del daño, han de comenzar por reconocer que con mucha frecuencia los factores sociales, situacionales y culturales, en combinación con los hábitos de consumo de drogas, condicionan la relación entre consumo de drogas y conducta sexual de riesgo. Este principio impone la necesidad de seguir estudiando y describiendo la influencia de los ambientes recreativos como factores ambientales para el consumo de alcohol y drogas y para las conductas sexuales de riesgo y de explicar de mejor forma la interacción entre esas tres variables entre los jóvenes clientes de discotecas portugueses.

\section{REFERENCIAS/ REFERENCES}

1. Calafat $A$, Juan $M$, Becoña $E$, Fernández $C$, Gil E, Palmer $A$, et al. Salir de marcha y consumo de drogas. Madrid: Ministerio del Interior, Delegación del Gobierno para el Plan Nacional sobre Drogas; 2000.

2. Deehan A, Saville E. Calculating the risk: recreational drug use among clubbers in the South East of England. Home Office Online Report 43/03. London: Home Office; 2003.

3. Lomba L. 0 consumo recreativo de ecstasy In: Relvas J, Lomba L, Mendes M. - Novas drogas e ambientes recreativos. Loures: Lusociência; 2006. p. 45-60.

4. Measham F, Aldridge J, Parker H. Dancing on drugs: risk, health and hedonism in the British Club Scene. London: Free Association Press; 2001.

5. Silva V. Techno, House e Trance: uma incursão pelas culturas da "dance music". Toxicodependências 2006;11:63-73.

6. Measham F, Aldridge J, Parker $\mathrm{H}$. The teenage transition: from adolescent recreational drug use to the young adult dance culture in Britain in the mid 1990s. J Drug Issues, Special Edition (Contemporary Issues Concerning Illicit Drug Use in the British Isles) 1998;28:9-32.

7. ESPAD. The 2007 ESPAD Report. Substance use among students in 35 European Countries. Sweden: European School Survey on Alcohol and other Drugs; 2009.

8. Balsa C, Vital C, Urbano C, Pascoeiro L. II Inquérito Nacional ao Consumo de Substâncias Psicoactivas na População Portuguesa high-risk sexual behaviour, drug use leads to high-risk sex, high-risk sex leads to drug use, or some other combination.

Given the fact that there is an increasingly high number of nightlife recreational settings and that they are increasingly popular with young people, a focus on these risk environments is an essential public health issue, instead of concentrating on defining risk epidemiologically as contemporary public health studies on addictions have been doing almost exclusively ${ }^{63}$. Rhodes ${ }^{56}$ suggests that it is essential to discuss the social situations and places within which harm is produced and reduced.

If future research is to maintain a practical contribution to the design and implementation of harm reduction intervention, then a primary focus of such research has to be the acknowledgment of the high possibility that social, situational and cultural factors, in combination with drug taking practices, may determine the nature of relationships between drug use and sexual risk behaviour. This principle embraces the need to keep on studying and describing the influence of recreational settings as an environmental factor for alcohol and drug use and sexual risk behaviours, and to create a better understanding of the interaction between these three variables among young Portuguese clubbers.

- 2007. Lisboa: CEOS, Faculdade de Ciências Sociais e Humanas da Universidade Nova de Lisboa; 2007.

9. EMCDDA. National Report (2006 data) to the EMCDDA by the Reitox National Focal Point. Portugal. New development trends and in-depth information on selected issues. Lisboa: EMCDDA; 2007.

10. Bellis $\mathrm{M}$, Hughes $\mathrm{K}$, Lowey $\mathrm{H}$. Healthy night clubs and recreational substance use: from a harm minimisation to a healthy settings approach. Addict Beahav 2002; 27: 1025-35.

11. Pardo L. El ocio y el tiempo libre como espacio de riesgo y sus posibilidades en prevención. In: Achirica A, Arnedillo G, Arnedillo J, Pardo L. La prevención de las drogodependencias en el tiempo de ocio. Manual de formación. Madrid: Asociación Deporte y Vida; 2002. p. 11-16.

12. Calafat $A$, Gómez $C$, Juan $M$, Becoña E. Gestión de la vida recreativa: ¿Un factor de riesgo determinante en el uso reciente de drogas? Adicciones 2005;17:337-47.

13. Measham, F. and Moore, K. Repertoires of Distinction: Exploring Patterns of Weekend Polydrug Use within Local Leisure Scenes across the English Night Time Economy, Criminology and Criminal Justice, 2009, 9 (4). See also Farrell A. Risk factors for drug use in urban adolescents: a three-wave longitudinal study. J Drug Issues 1993;23:443-62.

14. Suárez J, Tomás $E$, Tomás $M$. Jóvenes, fin de semana y uso recreativo de drogas: evolución y tendencias del ocio juvenil. Addiction 2003;15:7-33.

15. EMCDDA. National Report (2005 data) to the EMCDDA by the Reitox National Focal Point. Portugal. New development trends 
and in-depth information on selected issues. Lisboa: EMCDDA; 2006.

16. Becoña $E$, Juan $M$, Calafat $A$, Ros $M$. Razones para no aceptar una relación sexual en jóvenes que se divierten en contextos recreativos nocturnos en función del género y la embriaguez. Adicciones 2008;20:357-364

17. Centers for Disease Control and Prevention. CDC Fact Book 2000/2001. [Online]. Washington: Department of Health and Human Services. Available from: URL:http://www.cdc.gov/maso/ factbook/

18. Calafat A, Jerez M, Iglesias E, Gómez C. Mediadores recreativos y drogas. Nueva área para la prevención. Palma de Mallorca: IREFREA; 2007.

19. Gorman M. A tale of two epidemics: HIV and stimulant use. Focus 1998;13:1-3.

20. Hayaki J, Anderson B, Stein M. Sexual risk behaviours among substance users: relationship to impulsivity. Psychol Addict Behav 2006;20:328-32.

21. Rhodes T. Drogas e comportamentos sexuais de risco. Site álcool e drogas sem distorção. Programa álcool e drogas (PDA). [Online]. São Paulo: Hospital Israelita Albert Einstein. Available from: URL:http://www.einstein.br/alcooledrogas

22. Poulin C, Graham L. The association between substance use, unplanned sexual intercourse and other sexual behaviours among adolescent students. Addiction 2001;96:607-21

23. Pechansky F, Inciardi A, Surratt $H_{\text {, Lima }}$, Kessler $P$, Soibelman $M$, et al. Estudo sobre as caracteristicas de usuários de drogas injetáveis que buscam atendimento em Porto Alegre. Revista Brasileira de Psiquiatria 2000;22:164-71.

24. Capdevila M. MDMA o el éxtasis químico. Barcelona: Los Libros de la Liebre de Marzo; 1995.

25. Viana L. Ecstasy: história, mitos \& factos. Toxicodependências 2002;8:65-77.

26. Souza D, Oliveira D. 0 perfil epidemiológico do uso de drogas entre estudantes de $1^{\circ}$ e $2^{\circ}$ graus da rede estadual de ensino de Cuiabá, Brasil. Saúde Pública 1998; 14: 391-400.

27. Castro D. Nuevas infecciones por el VIH: perfil del seroconvertor reciente (2000-2002). Publicación Oficial de la Sociedad Española Interdisciplinaria del SIDA 2003; 14.

28. James JS. "Poppers," Some others drugs, may increase HIV infection risk. AEGiS AIDS Treatment News 2004; Feb.18.

29. Fernández $P$, Hernández I. Características farmacológicas de las drogas recreativas (MDMA y otras anfetaminas, ketamina, GHB, LSD y otros alucinógenos). Adicciones 2003;15:51-75.

30. Calafat $A$, Juan $M$, Becoña $E$, Mantecón $A$. Qué drogas se prefieren para las relaciones sexuales en contextos recreativos. Adicciones 2008;20:37-48.

31. Bellis M, Hughes K. Pociones sexuales. Relación entre alcohol, drogas y sexo. Adicciones 2004;16:249-57.

32. Rhodes $T$, Stimson G. What is the relationship hetween drug taking and sexual risk? Social relations and social research. Sociol Health Illness 1994;16:209-28.

33. Järvinen $M$, Room R. Youth drinking cultures: European experiences. In: Järvinen $M$, Room R, editors. Youth drinking cultures. European experiences. Surrey, UK: Ashgate; 2007. p. 1-16.

34. World Health Organization. Global status report on alcohol 2004. Geneva: WHO, Department of Mental Health and Substance Abuse; 2004.
35. Room R. Understanding cultural differences in young people's drinking. In: Järvinen $M$, Room $R$, editores. Youth Drinking Cultures. European Experiences. Surrey, UK: Ashgate; 2007. p. 17-40.

36. Abrahamson M. Alcohol in courtship contexts: focus-group interviews with young Swedish women and men. Contemp Drug Problems 2004;31:3-29.

37. Martin L. Alcohol, sex and gender in late medieval and early modern Europe. New York: Palgrave Macmillan; 2001.

38. Bonomo Y, Coffey C, Wolfe R, Lynskey M, Bowes G, Patton G. Adverse outcomes of alcohol use in adolescents. Addiction 2001;96:1485-96.

39. Traeen B, Kvalem L. Sex under the influence of alcohol among Norwegian adolescents. Addiction 1996;91:995-1006.

40. Camera S, Sarriera J, Carlotto M. Predictores de conductas sexuales de riesgo entre adolescentes. Revista Interamericana de Psicologia/Interam J Psychol 2007;41:161-66.

41. Johnson J, Stahl, C. Sexual experiences associated with participation in drinking games. J Gen Psychol 2004;131:304-30.

42. Centers for Disease Control and Prevention. Youth risk behavior surveillance -United States, 2005. Morbidity and Mortality Weekly Report 2006;55SS-5.

43. DiClemente RJ, Wingood GM, Crosby R, Cobb BK, Harrinton K, Davies SL. Parent-adolescent communication and sexual risk behaviours among African adolescents females. J Pediatr 2001;139:407-12.

44. Whitaker D, Miller K. Parent-adolescent discussions about sex and condoms: impact on peer influences of sexual risk behaviour. J Adolesc Research 2000;15:251-73.

45. Matos $M$, Simões $C$, Tomé $G$, Pereira S, Diniz J. Comportamento sexual e conhecimentos, crenças e atitudes face ao VIH/SIDA: relatório preliminar, Dezembro 2006. [Online]. Available from: URL:http://www.fmh.utl.pt/aventurasocial

46. Reis $M$, Matos $M$. Contracepção em jovens universitários portugueses. Análise Psicológica 2008;1: 71-9.

47. Calafat $A$, Fernández $C$, Juan $M$, Anttila $A$, Bellis $M$, Bohrn $K$, et al. Cultural mediators in a hegemonic nightlife. Opportunities for drug prevention. Palma de Mallorca: IREFREA; 2004.

48. Megias I, Rodríguez E, Mendez S, Pallares J. Jóvenes y sexo: el estereotipo que obliga y el rito que identifica. Madrid: Injuve y Fundación de Ayuda contra la Drogadicción; 2005.

49. Cooper AL, Richter DL, Valois RF, Mackeown RE, Garrison CZ, Vincent, ML. Correlates and consequences of early initiation of sexual intercouse. J Sch Health 1994;64:372-77.

50. Heckathorn D. Respondent-driven sampling: a new approach to the study of hidden populations. Social Problems 1997:44:174-99.

51. Wang J, Carlson G, Falck S, Siegal A, Rahman A, Li L. Respondentdriven sampling to recruit MDMA users: a methodological assessment. Drug Alcohol Depend 2005; 78:147-57.

52. Lomba L, Apostolo J, Mendes F, Loureiro H, Graveto J, Silva, M. Consumos e comportamentos sexuais de risco na noite de Coimbra. Toxicodependências 2008; 14: 31-47.

53. Mantecón A, Juan $M$, Calafat $A$, Becoña $E$, Román E. Respondentdriven sampling: un nuevo método de muestreo para el estudio de poblaciones visibles y ocultas. Adicciones 2008;20:161-70.

54. Parker, H, Aldridge, J. and Measham, F, Illegal Leisure: The normalization of adolescent recreational drug use. London: Routledge, 1998. See also Parker H, Williams L, Aldridge J. The Normalization of 'Sensible' recreational drug use: further 
evidence from the North West England Longitudinal Study. Sociology [Online] 2002; 36: 941-64. Available from: URL:http:// soc.sagepub.com/cgi/content/abstract/36/4/941

55. Rhodes T. Risk environments and drug harms: a social science for harm reduction approach. International J Drug Policy 2009;20:193-201.

56. Feijão F, Lavado E. Os adolescentes e a droga. Portugal/2003. Lisboa: IDT; 2004.

57. Instituto da Droga e da Toxicodependência. Relatório anual 2006 - a situação do país em matéria de drogas e toxicodependências. Lisboa: IDT; 2007.

58. Observatório Europeu da Droga e da Toxicodependência. Relatório anual 2007. A Evolução do fenómeno da droga na Europa. Luxemburgo: Serviço das Publicações Oficiais das Comunidades Europeias; 2007.
59. Schifano F, Tedeschi D. Recreational drugs' scenario and compulsory treatment in the United Kingdom. Int J Mental Health 2008; 37: 22-56

60. Williams L, Parker H. Alcohol, cannabis, ecstasy and cocaine: drugs of reasoned choice amongst young adult recreational drug users in England. International J Drug Policy 2001;12:397-413

61. Antunes $M$, Apóstolo J, Jardim M, Sousa P. Caracterização dos comportamentos sexuais de estudantes do ensino superior em Portugal. In: Actas do 11 ${ }^{\circ}$ Congresso Brasileiro de Sexualidade Humana; 2007; Recife, Brasil.

62. 62. Plant M, Plant M. Risk-Takers. Alcohol, drugs, sex and youth. London: Routledge; 2003.

63. 63. Rhodes T, Quirk A. Drug users' sexual relationships and the social organisation of risk: the sexual relationship as a site of risk management. Sociol Health IIIness 1998;1:199-228. 
